\title{
Flame Spray Pyrolysis of Precursors as a Route to Nano-mullite Powder: Powder Characterization and Sintering Behavior
}

\author{
Rita Baranwal, ${ }^{, \dagger, *}$ Maria P. Villar, ${ }^{\S}$ Rafael Garcia, ${ }^{\S}$ and Richard M. Laine ${ }^{\star, \dagger, \pi}$ \\ Department of Materials Science and Engineering, University of Michigan, Ann Arbor, Michigan 48109-2136 and \\ Department Ciencia de los Materiales e Ingenieria Metalurgica y Quimica Inorganica, University of Cadiz,
}

Puerto Real 11510, Spain

The flame spray pyrolysis of alcohol-soluble precursors allows the synthesis of mullite-composition nanopowders (average size of $\sim 60-100 \mathrm{~nm}$ ) that, when annealed carefully, provide processable nano-mullite powders. The powders have been characterized using several spectroscopic and microscopy methods, including thermal gravimetric analysis, differential thermal analysis, diffuse reflectance infrared Fourier transform spectroscopy, and transmission electron microscopy. Preliminary studies on the pressureless-sintering behavior of these powders are presented. Without additives or any efforts to optimize the process, powder compacts could be sintered to relative densities of $>90 \%$, with grain sizes of $<500 \mathrm{~nm}$ at $1600^{\circ} \mathrm{C}$.

\section{Introduction}

$\mathrm{M}$ ULLITE $\left(3 \mathrm{Al}_{2} \mathrm{O}_{3} \cdot 2 \mathrm{SiO}_{2}\right)$ is an often-studied material, because of its high melting point $\left(1830^{\circ} \mathrm{C}\right)$, low coefficient of thermal expansion $\left(\mathrm{CTE}=4.4 \times 10^{-6}-5 \times 10^{-6} /{ }^{\circ} \mathrm{C}\right)$, low thermal conductivity, high chemical stability, high thermal shock resistance, and excellent creep resistance. ${ }^{1-9}$ All these factors contribute to good high-temperature mechanical properties, especially in composites where mullite serves as the matrix material. ${ }^{4}$ For example, SiC-fiber-reinforced mullite composites offer bend strengths of $800 \mathrm{MPa}$ and toughnesses of $29 \mathrm{MPa} \cdot \mathrm{m}^{0.5}$, in comparison with values of $330 \mathrm{MPa}$ and $1-2 \mathrm{MPa}^{0.5}$ for monolithic mullite. ${ }^{4,5}$

The low thermal conductivity, low density, and low CTE of mullite make it useful for optical applications, e.g., as mid-infrared (3-5 $\mu \mathrm{m})$ windows. ${ }^{6,8}$ Its low dielectric constant (6-6.7), coupled with a smaller CTE mismatch to silicon $\left(4.4 \times 10^{-6}-5 \times\right.$ $\left.10^{-6} /{ }^{\circ} \mathrm{C}\right)$ than $\mathrm{Al}_{2} \mathrm{O}_{3}\left(7.2 \times 10^{-6}-8.8 \times 10^{-6} /{ }^{\circ} \mathrm{C}\right)$ also make it a valuable material for use in microelectronics packaging and substrates. $2,6,9,10$

Unfortunately, the good high-temperature stability (low atomicdiffusion rates) of mullite makes it difficult to process to full density with complete control of both the stoichiometry and microstructure, especially using solid-state reaction methods. Consequently, alternate approaches such as chemical processing in

R. Raj-contributing editor

Manuscript No. 188474. Received June 15, 2000; approved January 19, 2001.

This work was supported in part by the Army Research Office and NASA-Glenn (Cleveland, OH). Author RB would like to thank the National Physical Science Consortium and NASA-Lewis (now NASA-Glenn) for a graduate fellowship.

The work described here was conducted by author RB in partial fulfillment of a Ph.D. degree at the University of Michigan, Ann Arbor, MI

${ }^{*}$ Member, American Ceramic Society.

tDept. of Materials Sciences and Engineering, University of Michigan.

ॠNow at Bechtel-Bettis, Inc., Pittsburgh, PA 15206.

Now at Bechtel-Bettis, Inc., Pittsburgh, PA 15206.
${ }^{\$}$ Dept. Ciencia de los Materiales e Ingenieria Metalurgica Y Quimica Inorganica, University of Cadiz.

"Author to whom correspondence should be addressed. particular, have been explored. Chemical processing permits atomic mixing of the desired components at early stages, unlike traditional processing methods. Thus, several groups recently have used sol-gel processing to form single phase, orthorhombic mullite (o-mullite) at $\sim 1250^{\circ} \mathrm{C}$. ${ }^{1,8,11-13}$ This result represents an improvement in temperature of $400^{\circ} \mathrm{C}$, relative to conventional methods.

Sol-gel processing is useful to form powders, coatings, fibers, and high-surface-area microporous materials. Unfortunately, solgel processing is not particularly useful for forming dense monoliths, because of the extensive volume changes involved in converting wet, porous gels to fully sintered, dense monoliths. Furthermore, despite the high chemical homogeneity of sol-gelprocessed powders, low diffusion rates still present an obstacle to achieving high densities with coincident control of microstructure, especially using pressureless-sintering methods.

Polymer-precursor processing represents a complementary approach to sol-gel processing that also provides atomic mixing. This approach also provides access to fibers, films, and microporous materials; however, it also is problematic in processing dense monoliths, because ceramic yields are typically low, which, again, lead to excessive volume changes that thwart efforts to achieve near-net-shape processing with good control of the microstructure. However, polymer precursors can be easily designed to be either melt- or solution-processable, unlike sol-gel precursors; therefore, the opportunity exists to develop powder-filled precursor systems that do not suffer the volume changes of the precursor alone. Hence, the opportunity to fabricate near-net-shaped parts can be improved greatly.

In this regard, we recently described a low-cost mullite precursor that is made by dissolving the products of reactions (1) and (2) in ethyl alcohol:

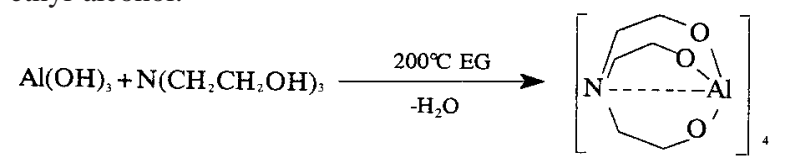

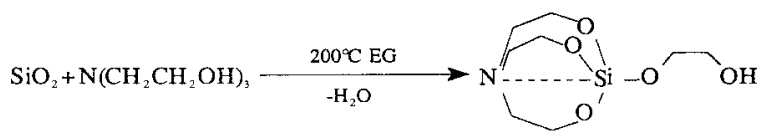

This atomically mixed precursor readily converts to stoichiometric tetragonal mullite ( $t$-mullite) and then $o$-mullite at relatively low temperatures. ${ }^{14}$

Coincident with the development of precursors such as those shown in reactions (1) and (2), we developed a simple method of producing ultrafine and nanosized ceramic powders by subjecting these same molecular and polymer precursors to flame spray pyrolysis (FSP). ${ }^{15,16}$ Here, we describe the use of the abovedescribed mullite precursor to synthesize nano-mullitecomposition powders and convert them to mullite (n-mullite) 
nanopowders. We also provide results from preliminary efforts to produce dense monoliths through the pressureless sintering of nanopowder compacts.

\section{Experimental Procedures}

\section{(1) Precursor Synthesis}

(A) General: All chemicals used in this study were used as-received, except ethylene glycol $\left(\mathrm{EGH}_{2}\right)$, which was distilled under nitrogen gas before use. $\mathrm{EGH}_{2}$ was recovered from the synthesis reactions described below and then redistilled and recycled.

(B) Synthesis of Mullite Precursor: The mullite precursor was synthesized using aluminum hydroxide hydrate $\left(\mathrm{Al}(\mathrm{OH})_{3} \cdot x \mathrm{H}_{2} \mathrm{O}, 54.6 \mathrm{wt} \% \mathrm{Al}_{2} \mathrm{O}_{3}\right.$ via thermogravimetric analysis (TGA); Aldrich Chemical Co., Inc., Milwaukee, WI), fumed silica $\left(\mathrm{SiO}_{2}\right.$, Cabot Corp., Tuscola, IL), laboratory-grade $\mathrm{EGH}_{2}$ (Fisher Scientific, Fair Lawn, NJ), and triethanolamine $\left(\mathrm{TEAH}_{3}\right)$ (Dow Chemical Co., Midland, MI).

(C) (TEAAl $)_{4}:$ Quantities of $\mathrm{Al}(\mathrm{OH})_{3} \cdot \mathrm{H}_{2} \mathrm{O} \quad(54.6$ wt $\%$ $\left.\mathrm{Al}_{2} \mathrm{O}_{3}\right)(1.8 \mathrm{~mol}, 168.0 \mathrm{~g}), \mathrm{TEAH}_{3}(1.8 \mathrm{~mol}, 268.5 \mathrm{~g})$, and $\mathrm{EGH}_{2}$ $(600-750 \mathrm{~mL}$ ) were reacted in a $2 \mathrm{~L}$ flask (via reaction (1)). The mixture was stirred and heated to $200^{\circ} \mathrm{C}$ (the boiling point of $\mathrm{EGH}_{2}$ ) under a nitrogen atmosphere. The reaction became clear after 3-4 h, after $600-700 \mathrm{~mL}$ of $\mathrm{EGH}_{2}$ and water had been distilled off. Vacuum evaporation was used to isolate the product. (This product is now commercially available from Tal Materials, Ann Arbor, MI.)

(D) TEA-Si-egH: Quantities of $\mathrm{SiO}_{2}(0.6 \mathrm{~mol}, 36.1 \mathrm{~g})$, $\mathrm{TEAH}_{3}(0.8 \mathrm{~mol}, 119.3 \mathrm{~g})$, and EGH $2(350-400 \mathrm{~mL})$ were reacted in a $1 \mathrm{~L}$ flask (via reaction (2)). This mixture also was stirred and heated to $200^{\circ} \mathrm{C}$ under a nitrogen atmosphere. After 3-4 h and the distillative removal of $300-350 \mathrm{~mL}$ of $\mathrm{EGH}_{2}$ and water, the $\mathrm{SiO}_{2}$ dissolved and the reaction became clear. When the system was cooled, the product was isolated via filtration and washed with acetone. (This product, and the mullite precursor described below, are now commercially available from Tal Materials.)

(E) Mullite: The TEA-Si-egH solution was added to the previously synthesized (TEAAl) ${ }_{4}$ solution, stirred, and heated to $200^{\circ} \mathrm{C}$ under a nitrogen atmosphere to distill off an additional 50-100 mL of EG. When the system was cooled to room temperature, a clear, viscous, yellow solution resulted. The ceramic yield via TGA in air was $23 \%$. The low ceramic yield (versus a theoretical yield of $28.2 \%$ ) was likely due to the presence of unreacted $\mathrm{TEAH}_{3}$ and free $\mathrm{EGH}_{2}$. Additional details have been reported elsewhere. ${ }^{14,17}$ To prepare the resulting solution for FSP, it was diluted with $1.9 \mathrm{~L}$ of 200 -proof ethyl alcohol, which resulted in a 7-wt\%-ceramic-yield solution (via TGA).

$(F)$ Powder Synthesis: A schematic of the FSP apparatus used to prepare the mullite powders is shown in Fig. 1. The apparatus consists of a precursor reservoir, an aerosol generator, a combustion chamber, and electrostatic precipitators. The 7-wt\%ceramic-yield solution of the mullite precursor in ethyl alcohol is pumped $(50 \mathrm{~mL} / \mathrm{min})$ to the aerosol generator, from a $10 \mathrm{~L}$ reservoir, into the combustion chamber. The solution is atomized using oxygen gas to produce an aerosol, which is ignited using methane pilot torches. Combustion occurs at $>2000^{\circ} \mathrm{C}$, which produces nano-oxide powder. The powders are collected downstream (at a temperature of $\sim 500^{\circ} \mathrm{C}$ ) in parallel electrostatic precipitators (ESPs) at a dc potential of $10 \mathrm{kV}$. The powder is recovered from the ESPs after 1-2 $\mathrm{h}$. A typical run requires $3-5 \mathrm{~h}$ at production rates of $100-300 \mathrm{~g} / \mathrm{h}$ (depending on the solids loading of the starting precursor solution), with an ESP collection efficiency of $\sim 80 \%$. A detailed description of this method has been reported elsewhere. ${ }^{15}$

(G) Powder Calcination: Small samples (2-5 g) of FSP mullite powder were calcined at a rate of $10^{\circ} \mathrm{C} / \mathrm{min}$ to $800^{\circ} \mathrm{C}$ (to remove residual water, carbon, or carbonates $(0.1-0.15 \mathrm{wt} \%$, via TGA)) and $1000^{\circ} \mathrm{C}$ (to fully crystallize $t$-mullite powder). Powders calcined at $800^{\circ}$ and $1000^{\circ} \mathrm{C}$ were used for most comparative

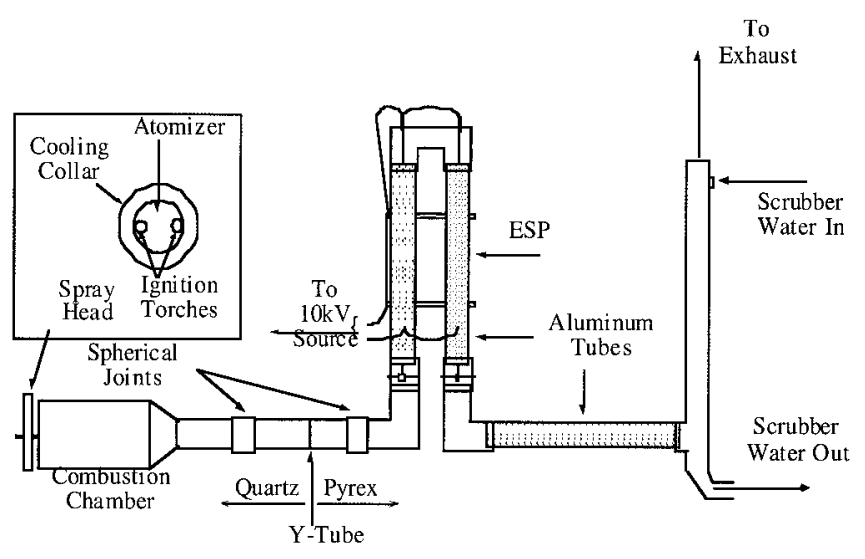

Fig. 1. Schematic of the flame spray pyrolysis (FSP) apparatus. Distance from spray head to Y-tube is $1 \mathrm{~m}$, rates of $100-400 \mathrm{~g} / \mathrm{h} . \phi=15-100 \mathrm{~nm}$ (average).

studies. Additional powder samples (1-2 g) were heated at $1200^{\circ}-1600^{\circ} \mathrm{C}$ for $2 \mathrm{~h}$ for analysis via X-ray diffractometry (XRD) and diffuse reflectance infrared Fourier transform spectroscopy (DRIFTS)

\section{(2) Characterization}

The as-processed powders, powders that were calcined at $800^{\circ}$ or $1000^{\circ} \mathrm{C}$ for $5 \mathrm{~h}$, and sintered compacts (using the method described below) were characterized using various methods. These methods include TGA, differential thermal analysis (DTA), differential scanning calorimetry (DSC), XRD, DRIFTS, gas sorption, wet chemical analysis (for carbon, nitrogen, and hydrogen), scanning electron microscopy (SEM), and transmission electron microscopy (TEM)

(A) Gas Sorption: Measurement of the specific surface areas (SSAs) and micropore analyses were conducted at $-196^{\circ} \mathrm{C}(77 \mathrm{~K})$, using a sorption analyzer (Model ASAP 2000, Micromeritics Instrument Group, Norcross, GA) with nitrogen as the adsorbate gas. The samples were degassed at $110^{\circ} \mathrm{C}$ for $4 \mathrm{~h}$, then at $400^{\circ} \mathrm{C}$ until the outgas rate was $<5 \mathrm{~mm} \mathrm{Hg} / \mathrm{min}$ (typically $4 \mathrm{~h}$ ). SSAs were calculated via the Brunauer-Emmett-Teller (BET) multipoint method, using at least five data points with relative pressures of $0.001-0.20$. Micropore analyses were conducted using a software package that was supplied with the instrument.

(B) Chemical Analysis: Elemental analyses for carbon, nitrogen, and hydrogen (CHN analysis) were performed using a CHN elemental analyzer (Model 2400, Perkin-Elmer, Norwalk, CT) that was operated at $1000^{\circ} \mathrm{C}$ (combustion tube) and $640^{\circ} \mathrm{C}$ (reduction tube) with helium as the carrier gas. Duplicate analyses were performed. The detection limit of the instrument was $0.1 \%$.

(C) Thermogravimetry/Differential Thermal Analysis: Thermal analyses (TGA and DTA) of the mullite precursor and as-collected mullite powders were performed (Model SDT 2960 Simultaneous DTA-TGA, TA Instruments, Inc., New Castle, DE). Gold was used to calibrate the instrument. The measurements (40 mg samples) were performed using $\mathrm{Al}_{2} \mathrm{O}_{3}$ crucibles in flowing air $(100 \mathrm{~mL} / \mathrm{min})$; rates of $10^{\circ}-50^{\circ} \mathrm{C} / \mathrm{min}$ to $1400^{\circ} \mathrm{C}$ were used. Calcined $\mathrm{Al}_{2} \mathrm{O}_{3}$ (Alcoa, Pittsburgh, PA) was used as a reference.

(D) Particle-Size Analysis: Particle-size distributions were measured using a particle analyzer (Model pK Acoustophor 8000, Pen Kem, Bedford Hills, NY). The analyzer uses an electroacoustic technique that exposes a particle slurry to sound waves. A particle-size distribution is calculated from the attenuation of the sound waves.

(E) X-ray Diffractometry: Powder and compact samples were analyzed by powder XRD, using a rotating-anode goniometer (Rigaku Denki Co., Ltd., Tokyo, Japan). Sintered compacts were ground to a powder $(100 \mathrm{mg})$, using an $\mathrm{Al}_{2} \mathrm{O}_{3}$ mortar and pestle. The powder was packed into a glass specimen holder and placed into the goniometer. Scans were measured over a $2 \theta$ range of $5^{\circ}-80^{\circ}$ at a scan rate of $10^{\circ} 2 \theta / \mathrm{min}$, using increments of $0.05^{\circ} 2 \theta$ 
and $\mathrm{Cu} K \alpha$ radiation $(\lambda=1.542 \AA)$; the apparatus was operated at $40 \mathrm{kV}$ and $100 \mathrm{~mA}$. Scans that were used to compare the integrated peak intensities of the (120) and (210) peaks were obtained at a rate of $1^{\circ} 2 \theta / \mathrm{min}$, using increments of $0.05^{\circ} 2 \theta$. The peak positions and relative intensities of the powder patterns were identified by comparison with ICDD $^{\dagger \dagger}$ data (ICDD Powder Diffraction File Card No. 15-776).

(F) Diffuse Reflectance Infrared Fourier Transform Spectroscopy: DRIFT spectra of the powder and compact samples were recorded on a spectrometer (Model Galaxy Series FTIR 3000, Mattson Instruments, Inc., Madison, WI). Random single-crystal potassium bromide $(\mathrm{KBr})$ (International Crystal Laboratories, Garfield, $\mathrm{NJ}$ ) was ground using an $\mathrm{Al}_{2} \mathrm{O}_{3}$ mortar and pestle. The ground $\mathrm{KBr}$ powder was used as the nonabsorbing medium. DRIFTS samples were prepared in air, using the following procedure: (i) $0.5 \mathrm{wt} \%$ of analyte was mixed rigorously with ground $\mathrm{KBr}$; (ii) $10 \mathrm{mg}$ of ground sample was added to $200 \mathrm{mg}$ of ground $\mathrm{KBr}$, and this mixture was ground together; (iii) then, 50 $\mathrm{mg}$ of this resulting mixture was ground together with $400 \mathrm{mg}$ of ground $\mathrm{KBr}$. Then, the dilute samples were packed into sample holders, leveled off, and transferred to the sample chamber, which was constantly flushed with nitrogen gas. A minimum of 250 scans was collected for each sample, at a resolution of $\pm 4 \mathrm{~cm}^{-1}$.

(G) Scanning Electron Microscopy: Grain evolution and growth were examined using an SEM system (Model S-800, Hitachi, Tokyo, Japan) that was operated at an acceleration voltage of $5 \mathrm{keV}$. The samples were prepared for SEM analysis by mounting the powder and fractured-compact samples on an aluminum stub, using double-sided tape. Then, the samples were sputter-coated with two layers $\left(45^{\circ}\right.$ and $-45^{\circ}$ off-axis) of $\mathrm{Au} / \mathrm{Pd}$ for $90 \mathrm{~s}$ at a potential of $10 \mathrm{mV}$, to reduce particle charging. Line-fraction analyses were used to determine the average particle size.

(H) Transmission Electron Microscopy: Powder particles were analyzed at the Microscopy/High Resolution Electron Microscopy (TEM/HREM and SEM) facilities at the University of Cadiz, using a TEM system (Model 2000-EX, JEOL, Tokyo, Japan) that was equipped with a top-entry specimen holder and an ion-pumping system. This TEM system was operated at an accelerating voltage of $200 \mathrm{kV}$, with a nominal structural resolution of $0.21 \mathrm{~nm}$. Samples were prepared for TEM analysis by dipping a holey carbon copper grid into an ultrasonic dispersion of the mullite powders in hexane.

Micrographs were taken over a range of magnifications. The images were developed chemically; then, the micrographs were digitized, using a charge-coupled device (CCD) camera, and then processed and analyzed using the SEMPER $6^{+}$software package (Synoptics, Cambridge, U.K.). The crystal-size distribution was obtained by measuring the size (longest apparent width) of a large population $(\sim 300)$ of crystals from micrographs that were taken over a range of magnifications.

\section{(3) Compact Processing}

(A) Pressing of Powder Compacts: Compacts were formed by loading $1.00 \pm 0.10 \mathrm{~g}$ of FSP-processed mullite-composition powders or heat-treated powders into a stainless-steel doubleaction die (diameter $(d)$ of $12.75 \mathrm{~mm}$ ) and pressing in a laboratory press (Model 3912, Carver). No additives or binders were used.

Before final compaction, the powders were granulated as follows. Powder was compacted at loads of 90 or $180 \mathrm{MPa}$ for $10 \mathrm{~min}$ in air (i.e., $90 \mathrm{MPa} / 10 \mathrm{~min} / \mathrm{air}$ ). The compacts were removed from the die and ground with an $\mathrm{Al}_{2} \mathrm{O}_{3}$ mortar and pestle. Then, this "granulated powder" was loaded into the die and pressed again at $90 \mathrm{MPa} / 10 \mathrm{~min} / \mathrm{air}$ or $180 \mathrm{MPa} / 10 \mathrm{~min} / \mathrm{air}$. The dimensions and mass of the compact were used to obtain green densities. The formed compacts $(d=12.75 \pm 0.05 \mathrm{~mm}$, thickness

${ }^{\dagger}$ International Center for Diffraction Data, Newtown Square, PA (formerly Joint Committee on Powder Diffraction Standards (JCPDS), Swarthmore, PA). $(t)$ of $3.30 \pm 0.30 \mathrm{~mm}$ ) had a green density $\left(\rho_{\text {green }}\right)$ of $46 \%-50 \%$, relative to the theoretical density $\left(\rho_{\text {theoretical }}\right)$, for the $90 \mathrm{MPa}$ compacts and $\rho_{\text {green }}=42 \%-44 \%$ of $\rho_{\text {theoretical }}$ for the $180 \mathrm{MPa}$ compacts. The compacts were sintered subsequently at selected temperatures.

(B) Sintering Conditions: Sintering was conducted in a box furnace (Model 58114, Lindberg/Blue, Watertown WI) that was controlled by a microprocessor (Model 818P, Eurotherm, Northing, England). Powder compacts were heated at ramp rates of $5^{\circ}-50^{\circ} \mathrm{C} / \mathrm{min}$ to $1600^{\circ} \mathrm{C}$ and held for selected times $(2-24 \mathrm{~h})$. The sintered mass and size were used to determine the sintered densities. These values were corroborated with values obtained using the Archimedes method.

\section{Results and Discussion}

In the following sections, we first discuss the synthesis of flame spray pyrolysis (FSP) powder and powder characterization. Then, we discuss preliminary studies on the processing and sintering behavior of powder compacts.

\section{(1) Flame Spray Pyrolysis}

The nanopowders used below were produced via FSP of the precursors from reactions (1) and (2) that were dissolved in ethyl alcohol. In the FSP process, ethyl alcohol solutions that contained $7 \mathrm{wt} \%$ ceramic (as a precursor) were ultrasonically aerosolized with oxygen in a quartz combustion chamber, as illustrated in Fig. 1, and ignited. The ensuing combustion results in flame temperatures of $1600^{\circ}-2000^{\circ} \mathrm{C}$, depending on the solvent, precursor loading, and rate of aerosolization. ${ }^{15,16}$

Combustion of the precursor forms metal-oxide vapors that likely consist of gaseous atoms, ions, and molecular-oxide species (e.g., $\mathrm{M}-\mathrm{O}$ "monomers," $<5 \AA$ in size), which co-react to form clusters (e.g., $(\mathrm{M}-\mathrm{O})_{x}$, where $x \approx 10 ;<5 \mathrm{~nm}$ in size) that then coalesce to form larger particles $\left(>10 \mathrm{~nm}\right.$ in size). ${ }^{18-20}$ These particles, in turn, form aggregates and agglomerates. A general process is suggested in Fig. 2.

Although gas-phase reactions can generate multimetallic oxides, ${ }^{21}$ the production of homogeneous materials is often difficult if the various gaseous species have different condensation rates. These differences occur because the vapor pressures of the gaseous species and/or the surface energies of the condensed oxides differ greatly and thereby affect which materials nucleate and grow from the multiple species present. ${ }^{22}$ One component often nucleates first, and the other component(s) may nucleate subsequently on the surface of existing particles or as new, single-component particles. $^{22}$ The result can be nonstoichiometric, inhomogeneous powders, even for nanoparticles.

For example, Chung et al. ${ }^{18}$ produced $\mathrm{Al}_{2} \mathrm{O}_{3}$ and $\mathrm{SiO}_{2}$ particles via the counterflow diffusion flame combustion of $\mathrm{AlCl}_{3}$ and/or $\mathrm{SiCl}_{4}$. In this process, a flow of oxygen/nitrogen gas is directed against a flow of $\mathrm{AlCl}_{3}$ or $\mathrm{SiCl}_{4} / \mathrm{H}_{2} / \mathrm{N}_{2}$. The impinging gas streams are ignited by a flame burner and flow outward. The combustion of $\mathrm{SiCl}_{4}$ and $\mathrm{AlCl}_{3}$ together produces particles with a mullite $\left(3 \mathrm{Al}_{2} \mathrm{O}_{3} \cdot 2 \mathrm{SiO}_{2}\right)$ composition. Mullite-composition powders produced at $2000^{\circ} \mathrm{C}$ were amorphous agglomerates that consisted of primary particles $20-30 \mathrm{~nm}$ in size. At $>2250^{\circ} \mathrm{C}$, the particles were spherical agglomerates $150 \pm 20 \mathrm{~nm}$ in size (according to light scattering; $150 \mathrm{~nm}$ according to TEM analysis) that were composed of poorly crystalline mullite and spinel, again consisting of primary particles $20-30 \mathrm{~nm}$ in size.

In situ light scattering, which was used to measure the particle size and number density (abundance), showed that the mullitecomposition particles formed at the same location in the reactor ( $6.5 \mathrm{~mm}$ from the flame center) as that when only $\mathrm{AlCl}_{3}$ was used to make $\mathrm{Al}_{2} \mathrm{O}_{3}$ particles. Thus, Chung et al. ${ }^{18}$ suggested that mullite-composition particles may nucleate from $\mathrm{Al}-\mathrm{O}$ clusters $\left((\mathrm{Al}-\mathrm{O})_{x}\right)$.

Chung et al. ${ }^{18}$ also discussed four possible stages for particle growth as the reactant gases, and then gaseous species, flow 


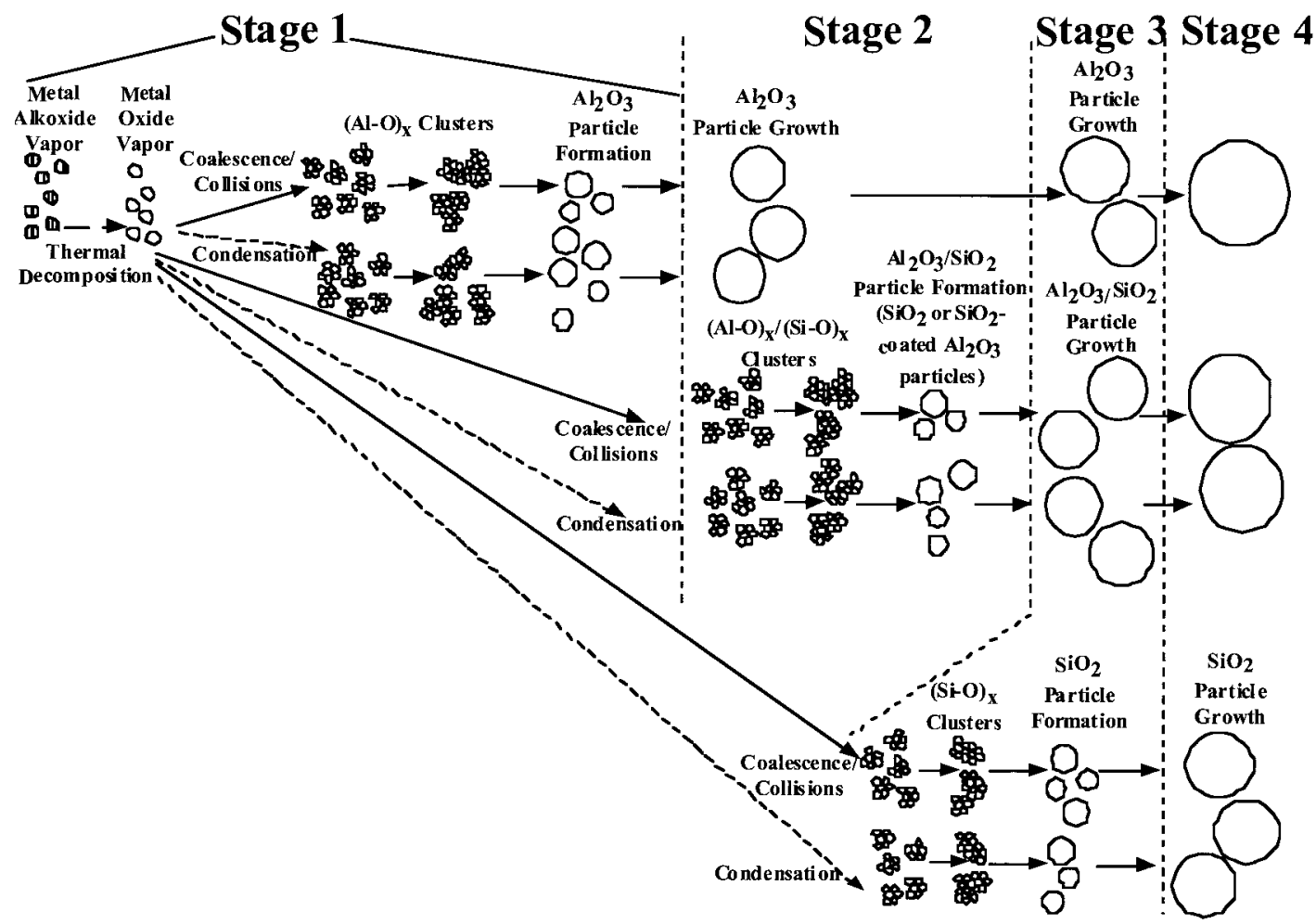

Fig. 2. General schematic depicting the possible gas-phase formation mechanisms of nanoparticles from a mullite-composition precursor.

toward the flame. In the first stage (farthest from the flame), particles form from the $\mathrm{Al}_{2} \mathrm{O}_{3}$ vapor, with sizes that increase from $60 \mathrm{~nm}$ to $130 \mathrm{~nm}$, with coincident decreases in number density from $2 \times 10^{8} / \mathrm{cm}^{3}$ to $2 \times 10^{7} / \mathrm{cm}^{3}$, which suggests growth via coagulation. Agglomerated particles form via coagulation when the rate of fusion is too slow to produce spherical particles. ${ }^{23}$

During the second stage (closer to the flame), $\mathrm{Al}_{2} \mathrm{O}_{3}$ "particles" continue to grow to a size of $\sim 170 \mathrm{~nm}$ as the particle number density increases to $5 \times 10^{8} / \mathrm{cm}^{3}$. The increase in number density likely results from the generation of agglomerated $\mathrm{SiO}_{2}$ "particles" from the $\mathrm{SiO}_{2}$ vapor, which condenses in the reactor closer to the flame center ( $3 \mathrm{~mm}$ vs $6 \mathrm{~mm}$ for the $\mathrm{Al}_{2} \mathrm{O}_{3}$ "particles"). Normally, one would expect $\mathrm{SiO}_{2}$ to condense at lower, not higher, temperatures (the condensation temperature of $\mathrm{Al}_{2} \mathrm{O}_{3}$ is $2470^{\circ} \mathrm{C}$ at a pressure of $2.7 \mathrm{kPa}$; the condensation temperature of $\mathrm{SiO}_{2}$ is $\sim 1800^{\circ} \mathrm{C}$ at the same pressure). ${ }^{24}$ However, the hydrolysis of $\mathrm{AlCl}_{3}$ occurs at lower temperatures than that for $\mathrm{SiCl}_{4}$, which results in an earlier formation of $\mathrm{Al}_{2} \mathrm{O}_{3}$ particles. This observation suggests that $\mathrm{M}-\mathrm{Cl}$ hydrolysis is the rate-limiting step in particle formation.

$\mathrm{SiO}_{2}$ vapor also can condense on existing $\mathrm{Al}_{2} \mathrm{O}_{3}$ and $\mathrm{SiO}_{2}$ "particles." The $\mathrm{SiO}_{2}$-coated $\mathrm{Al}_{2} \mathrm{O}_{3}$ "particles" thus formed, and vapor-derived $\mathrm{SiO}_{2}$ "particles," can grow via coagulation. Therefore, "particle" growth in the second stage results from both condensation and coagulation.

The third stage proceeds with the further generation of new "particles" via the nucleation of $\mathrm{SiO}_{2}$ vapor, further increasing the number density to $5 \times 10^{9} / \mathrm{cm}^{3}$; however, the fusion of previously formed agglomerates decreases the average "particle" size to $75 \mathrm{~nm}$. This observation implies that light-scattering techniques are measuring the agglomerate size rather than primary particle size. In the last stage, particles grow to $170 \mathrm{~nm}$ via coagulation and the particle number densities decrease to $7 \times 10^{8} \mathrm{~cm}^{3} .{ }^{18}$

Related literature on the processing of ultrafine mullitecomposition powders describes the formation of other phases in addition to, or before, the formation of $t$-mullite. Moore et al. ${ }^{25}$ spray-pyrolyzed aqueous $\mathrm{Al}\left(\mathrm{NO}_{3}\right)_{3} \cdot 9 \mathrm{H}_{2} \mathrm{O}$ and fumed $\mathrm{SiO}_{2}$ mixtures ( $7 \mathrm{wt} \%$ ceramic) by passing the solutions through a tube reactor that was heated to $900^{\circ} \mathrm{C}$, then in a second pass to $>1400^{\circ} \mathrm{C}$, with residence times of 15 and $30 \mathrm{~s}$, respectively. No efforts were made to reduce the particle sizes, which ranged from $100 \mathrm{~nm}$ to $4 \mathrm{~mm}\left(600 \mathrm{~nm}\right.$ on average) with SSAs of $6-7 \mathrm{~m}^{2} / \mathrm{g}$. XRD studies revealed that powders produced at $>1400^{\circ} \mathrm{C}$, with a 30 s residence time, were primarily amorphous with some $\gamma-\mathrm{Al}_{2} \mathrm{O}_{3}$. Powders produced at $1600^{\circ} \mathrm{C}$, with a residence time of $30 \mathrm{~s}$, were phase-pure mullite. The particle sizes of the $1400^{\circ}$ and $1600^{\circ} \mathrm{C}$ powders were not differentiated.

Suzuki et al. ${ }^{26}$ used sol-gel processing (with $\mathrm{Si}(\mathrm{OEt})_{4} /$ $\mathrm{Al}\left[\mathrm{OCH}\left(\mathrm{CH}_{3}\right)_{2}\right]_{3} /$ isobutyl alcohol) to produce powders that crystallized to Al-Si spinel at $980^{\circ} \mathrm{C}$ (according to XRD, DTA, and TEM) and then to phase-pure mullite at $>1200^{\circ} \mathrm{C}$ (according to XRD) (probably $o$-mullite, although it was not mentioned). This behavior is typical of an inhomogeneous, single-phase precursor. A small percentage of hard agglomerates were formed. Heating at $1100^{\circ} \mathrm{C}$ produced particles $6-11 \mathrm{~nm}$ in size (according to TEM) and $11-21 \mathrm{~nm}$ in size (according to BET analysis (SSAs $=89-167$ $\mathrm{m}^{2} / \mathrm{g}$ )). After conversion to mullite at $1500^{\circ} \mathrm{C}$ (XRD), SSAs were $6-38 \mathrm{~m}^{2} / \mathrm{g}$ and the final particle sizes were $50-320 \mathrm{~nm}$, according to BET. The particles seemed be agglomerated.

Ge et $a l^{27}$ also used the sol-gel method (with $\mathrm{Al}\left(\mathrm{NO}_{3}\right)_{3} \cdot 9 \mathrm{H}_{2} \mathrm{O} /$ $\left.\mathrm{Si}(\mathrm{OEt})_{4} / \mathrm{EtOH}\right)$ to process submicrometer mullite powders $(100$ $\mathrm{nm}-1.5 \mu \mathrm{m}$, with an average size of $560 \mathrm{~nm}$ ), using $\mathrm{HNO}_{3}$ as a catalyst. A single-phase gel that converted to $t$-mullite at $980^{\circ} \mathrm{C}$ (according to XRD) was formed. If $\mathrm{NH}_{4} \mathrm{OH}$ was used as a catalyst, particles with an $\mathrm{Al}_{2} \mathrm{O}_{3}$-rich core and a $\mathrm{SiO}_{2}$ shell precipitated. No explanation was given for this behavior. When the powders were heated to $980^{\circ} \mathrm{C}$, they were X-ray amorphous, with some Al-Si spinel. XRD studies showed a conversion to mullite at $1200^{\circ} \mathrm{C}$, which was consistent with an inhomogeneous, single-phase material. When powders were produced using a $\mathrm{CH}_{3} \mathrm{COONH}_{4}$ catalyst, a diphasic precursor formed, likely due to segregation of the $\mathrm{Al}$ and Si species. XRD studies revealed the presence of the following compounds: after heating to $980^{\circ} \mathrm{C}$, amorphous powders, with some mullite and $\gamma-\mathrm{Al}_{2} \mathrm{O}_{3}$; after heating to $1200^{\circ} \mathrm{C}$, mullite and some $\alpha-\mathrm{Al}_{2} \mathrm{O}_{3}$; and after heating to $1300^{\circ} \mathrm{C}$, phase-pure mullite.

The above-mentioned literature provides context for a discussion of particle formation in FSP-generated mullite-composition nanopowders. Several particle-formation scenarios are possible that are most easily identified by the behavior of the as-processed mullite powders when they are heated. Consider, for example, the 
behavior of nanopowders wherein $\mathrm{Al}_{2} \mathrm{O}_{3}$ and $\mathrm{SiO}_{2}$ particles nucleate and grow separately but coincidentally, with limited co-condensation. These materials should exhibit diphasic behavior when heated, as observed by Ge et $a .^{27}$ When these powders are heated, the first phase transformations to be observed will be the crystallization of mullite, $\gamma-\mathrm{Al}_{2} \mathrm{O}_{3}$, and/or a spinel phase at $<1000^{\circ} \mathrm{C}$, followed by the crystallization of more mullite and $\alpha-\mathrm{Al}_{2} \mathrm{O}_{3}$ at $>1200^{\circ} \mathrm{C}$, with full crystallization to mullite at $\sim 1300^{\circ} \mathrm{C}$. Similar diphasic behavior might be expected for coreshell particles wherein $\mathrm{Al}_{2} \mathrm{O}_{3}$ cores form first, based on Chung et al. ${ }^{18}$ followed by $\mathrm{SiO}_{2}$ coatings. One potential issue is whether the diffusion distances in the core-shell particles are sufficiently great to cause diphasic behavior.

A less-extreme particle-formation process would produce particles with only partial segregation (or partial mixing). For example, one might expect $\mathrm{Al}_{2} \mathrm{O}_{3}$ clusters to form first and then nucleate growth of a co-condensed phase simply because there are more $\mathrm{Al}_{2} \mathrm{O}_{3}$ species in the gas phase. For particles of this type, one might expect to see behavior similar to that observed by Suzuki et al. ${ }^{26}$ wherein the typical exotherm at $980^{\circ} \mathrm{C}$ leads to the crystallization of $t$-mullite and/or a spinel phase, followed by phase-pure mullite at $>1200^{\circ} \mathrm{C}$.

The most-desirable processing scenario is one in which complete mixing is obtained. If this scenario occurs, then three possible FSP outcomes can be expected: (i) particles form and crystallize in the form of mullite ( $o$ - and/or $t$-mullite), (ii) partial crystallization occurs, and (iii) amorphous powders are produced. In the latter two instances, a typical exotherm, which corresponds to the formation of $t$-mullite $(\mathrm{Si}: \mathrm{Al} \approx 1: 5)$ and nano-segregation of $\mathrm{SiO}_{2}$, will be observed at $980^{\circ} \mathrm{C}$. Then, the crystallization of $o$-mullite $(\mathrm{Si}: \mathrm{Al} \approx$ 1:3) will occur at $>1200^{\circ} \mathrm{C}$, as observed for atomically mixed, precursor-derived materials. ${ }^{14,28,29}$ As discussed below, partially crystalline powders are produced.

Of the above-cited literature, the efforts of Chung et al. ${ }^{18}$ are most similar to the FSP processing of n-powders; however, considerable differences remain. For example, FSP combusts metal alkoxides; therefore, combustion only needs to strip away the organic components to generate gas-phase $\mathrm{Si}-\mathrm{O}$ and $\mathrm{Al}-\mathrm{O}$ species. Thus, the distribution of $\mathrm{Si}-\mathrm{O}$ and $\mathrm{Al}-\mathrm{O}$ species in the gas phase should be similar to the initial composition in the solution phase. Furthermore, combustion heats the precursor species directly to the highest temperature, followed by a very steep $\left(>1500^{\circ} \mathrm{C}\right)$ quench. ${ }^{15}$ In contrast, counterflow diffusion flames heat the precursor to increasingly higher temperatures under conditions where rapid quenching is not observed. Thus, the particle-formation processes may be entirely different. Given these perspectives, we can now discuss the characterization of the as-processed FSP mullite-composition powders.

\section{(2) Surface Area Analysis}

BET analyses of as-processed powders give SSAs of $43 \pm 1$ $\mathrm{m}^{2} / \mathrm{g}$ (for a grouping of five samples). BET SSAs and a density of $3.156 \mathrm{~g} / \mathrm{cm}^{3}$ were used to calculate an average particle diameter $\left(D_{\mathrm{BET}}\right)$ of $44 \pm 2 \mathrm{~nm}$. The SSA of heated, uncompacted powder decreases from $43 \mathrm{~m}^{2} / \mathrm{g}$ at $600^{\circ} \mathrm{C}$ to $0.4 \mathrm{~m}^{2} / \mathrm{g}$ at $1600^{\circ} \mathrm{C}$. The loss of surface area on heating is indicative of grain growth, as confirmed by SEM studies. Table I lists the calculated $D_{\mathrm{BET}}$ values

Table I. XRD Mean Crystallite Size and BET Particle Size of Crystallized Nano-mullite

\begin{tabular}{ccc}
\hline Sample conditions & $\begin{array}{c}\text { XRD mean crystallite size } \\
(\mathrm{nm})\end{array}$ & $\begin{array}{c}\mathrm{BET}^{\dagger} \\
D_{\mathrm{BET}^{*}(\mathrm{~nm})}\end{array}$ \\
\hline $900^{\circ} \mathrm{C}$ for $10 \mathrm{~h}$ in air & 34.4 & 51 \\
$1000^{\circ} \mathrm{C}$ for $5 \mathrm{~h}$ in air & 38.8 & 66 \\
$1200^{\circ} \mathrm{C}$ for 2 $\mathrm{h}$ in air & 44.9 & 80 \\
$1400^{\circ} \mathrm{C}$ for 2 $\mathrm{h}$ in air & 58.8 & 5261 \\
$1600^{\circ} \mathrm{C}$ for 2 $\mathrm{h}$ in air & 113.7 & \\
\hline
\end{tabular}

${ }^{\dagger}$ Standard deviation of $\pm 0.2 \mathrm{~nm}$. ${ }^{*}$ Standard deviation of $\pm 2.5 \mathrm{~nm}$. of crystallized samples (from $50 \mathrm{~nm}$ at $900^{\circ} \mathrm{C}$ for $10 \mathrm{~h}$ to $5.2 \mu \mathrm{m}$ at $\left.1600^{\circ} \mathrm{C}\right)$.

\section{(3) Wet Chemical Analysis}

CHN analyses give values below the detection limits $(<0.1 \mathrm{wt} \%)$ of the instrument for as-processed powders. Thus, only trace impurities are likely present at the powder surfaces.

\section{(4) Thermal Analyses}

The DTA profile (not shown) of as-processed powder $\left(10^{\circ} \mathrm{C} /\right.$ min/air) reveals only one event: an exotherm at $980^{\circ} \mathrm{C}$. The absence of any other exotherms suggests that the precursor is single phase and forms $t$-mullite directly, as also corroborated by XRD and FTIR studies. However, increasing the ramp rates to $30^{\circ}-50^{\circ} \mathrm{C} / \mathrm{min}$ retards the nucleation of mullite to $1005^{\circ} \mathrm{C}$. To the best of our knowledge, this is not an overshoot phenomenon, because it is observed in the sintering studies described below.

The DTA results are similar to those observed by Kansal et al.,${ }^{14}$ although they reported the formation of $t$-mullite at $990^{\circ} \mathrm{C}$ using polymer-precursor-derived powder. The conversion to $t$-mullite observed here, using as-processed mullite-composition n-powders (derived from the same polymer precursor used by Kansal et al. ${ }^{14}$ ), happens at a temperature that is $10^{\circ} \mathrm{C}$ lower than the Kansal et al. ${ }^{14}$ data. These differences may not be significant, although the lower crystallization temperature may indicate higher purity levels (the chemical analysis in the earlier studies shows that a trace of carbon was present).

\section{(5) Particle-Size Distribution}

The particle-size analysis of as-processed powders (no milling necessary) was obtained using electro-acoustic methods (see the experimental section). This particle-size analysis shows a broad log-normal size distribution (Fig. 3) between $10 \mathrm{~nm}$ and $1 \mu \mathrm{m}$.

The average particle size was $\sim 80 \mathrm{~nm}$. The log-normal size distribution argues against the presence of agglomerates; however, TEM analyses indicate that many particles actually consisted of primary particles that were joined to other primary particles by one or two necks. Thus, the particle size that was determined from the electro-acoustic particle-size distribution matched that determined through TEM studies. The particle size that was determined by SSA $\left(D_{\mathrm{BET}}\right)$ gives an average particle size of $44 \mathrm{~nm}$, which follows from the necking that was observed via TEM (see Figs. 4 and 5). The observation of a few necks suggests that the particles had time for only one or two collisions at or above the fusion temperatures,

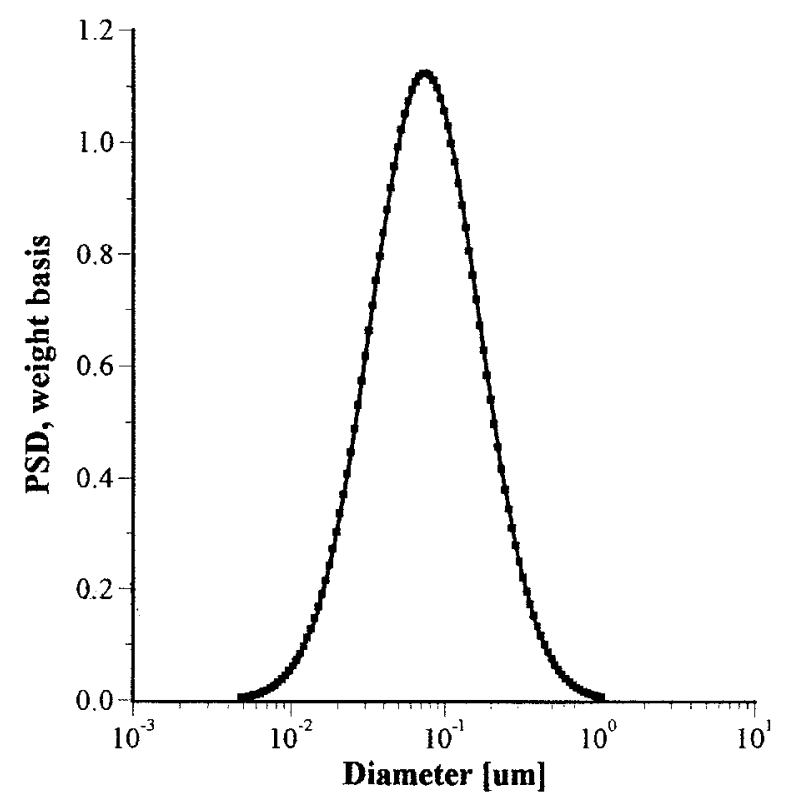

Fig. 3. Particle-size distribution (PSD) for mullite powder (as-collected). 


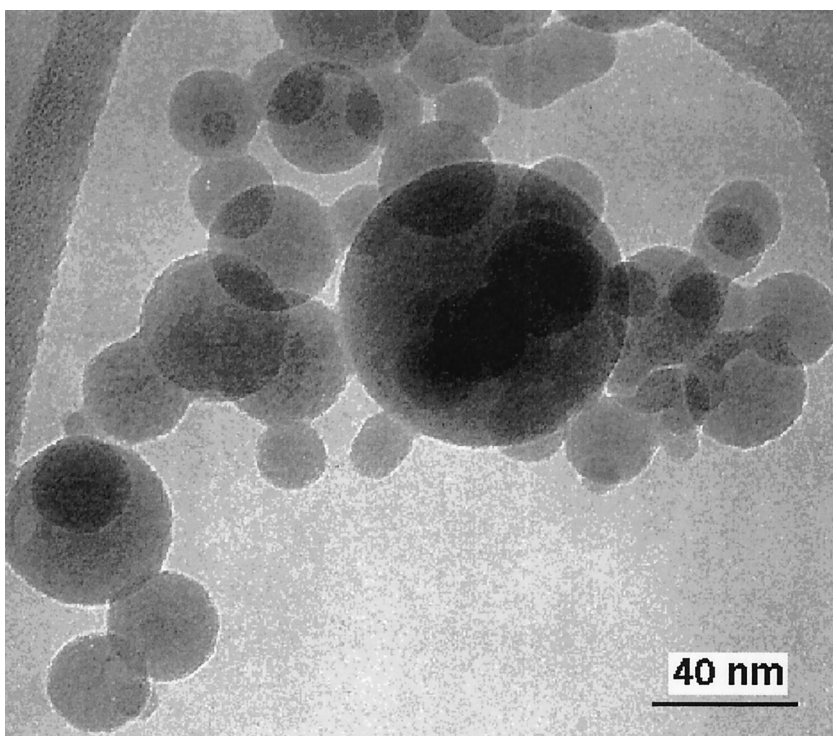

Fig. 4. TEM micrograph of as-processed mullite-composition nanopowder.

before quenching was effective. These results also suggest that the particles might be partially or fully melted at some point in the flame. Note that no change in the particle-size distributions occurred after annealing.

Barringer et al. ${ }^{30}$ claimed that narrow particle-size distributions $(10-500 \mathrm{~nm}$, with an average particle size of $80 \mathrm{~nm})$ are critical to the retention of a fine-grained structure in sintered compacts. This size range is suggested, to permit the formation of uniform green bodies that sinter without significant particle rearrangement (which leads to grain growth). Uniform powders, in turn, inhibit grain growth, because of the absence of particles with lower surface energies.

\section{(6) X-ray Diffractometry}

Powder XRD studies were used for phase identification and estimation of the particle size. XRD patterns of the as-processed and calcined powder samples (see Fig. 6) show that the as-

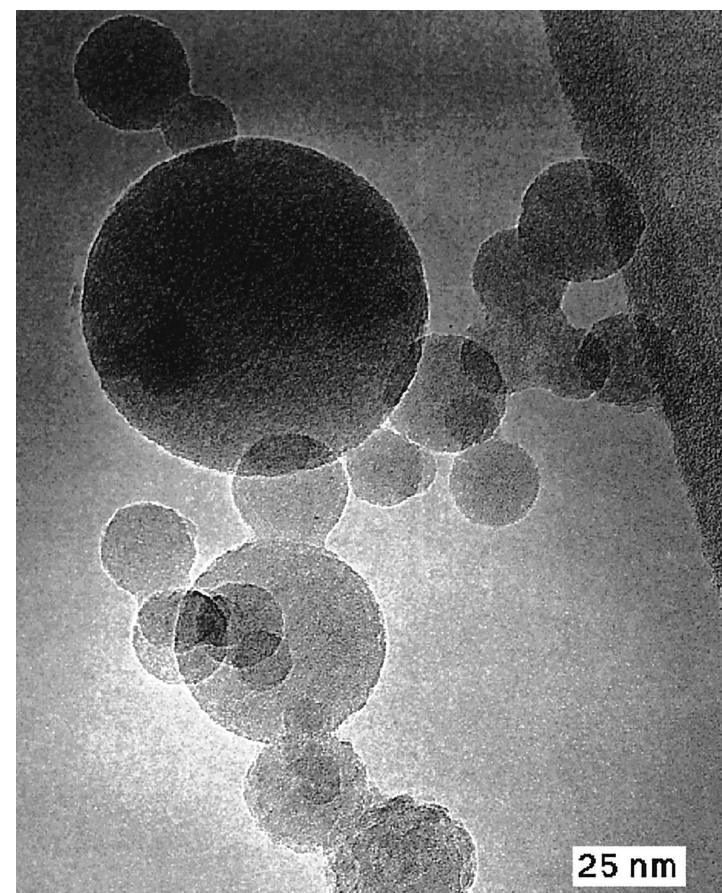

Fig. 5. TEM micrograph of mullite-composition nanopowder after heating at $1000^{\circ} \mathrm{C}$ for $5 \mathrm{~h}$ in air.

processed powder exhibits traces of crystallinity, which is consistent with mullite formation (in agreement with the TEM studies); however, the powder is primarily amorphous. When the powders are heated, they first convert to fully crystalline $t$-mullite at $1000^{\circ} \mathrm{C}$ (ICDD Powder Diffraction File Card No. 15-776). The conversion to $t$-mullite is corroborated by the DRIFTS data given below and follow from our earlier work and that of other researchers. ${ }^{14,29,31}$

XRD studies also were conducted to trace the conversion of $t$-mullite to $o$-mullite. Figure 7 shows the splitting of the (120) and (210) peaks at $26.15^{\circ} 2 \theta$ in $t$-mullite (which forms on heating to $900^{\circ} \mathrm{C}$ for $10 \mathrm{~h}$ ) into $25.97^{\circ}$ and $26.26^{\circ} 2 \theta$ in $o$-mullite. The splitting of this peak was used to estimate the percent conversion of the tetragonal phase to orthorhombic phase, per Thomson et $a l .{ }^{29}$ The ratio of integrated peak intensities for the (120) and (210)

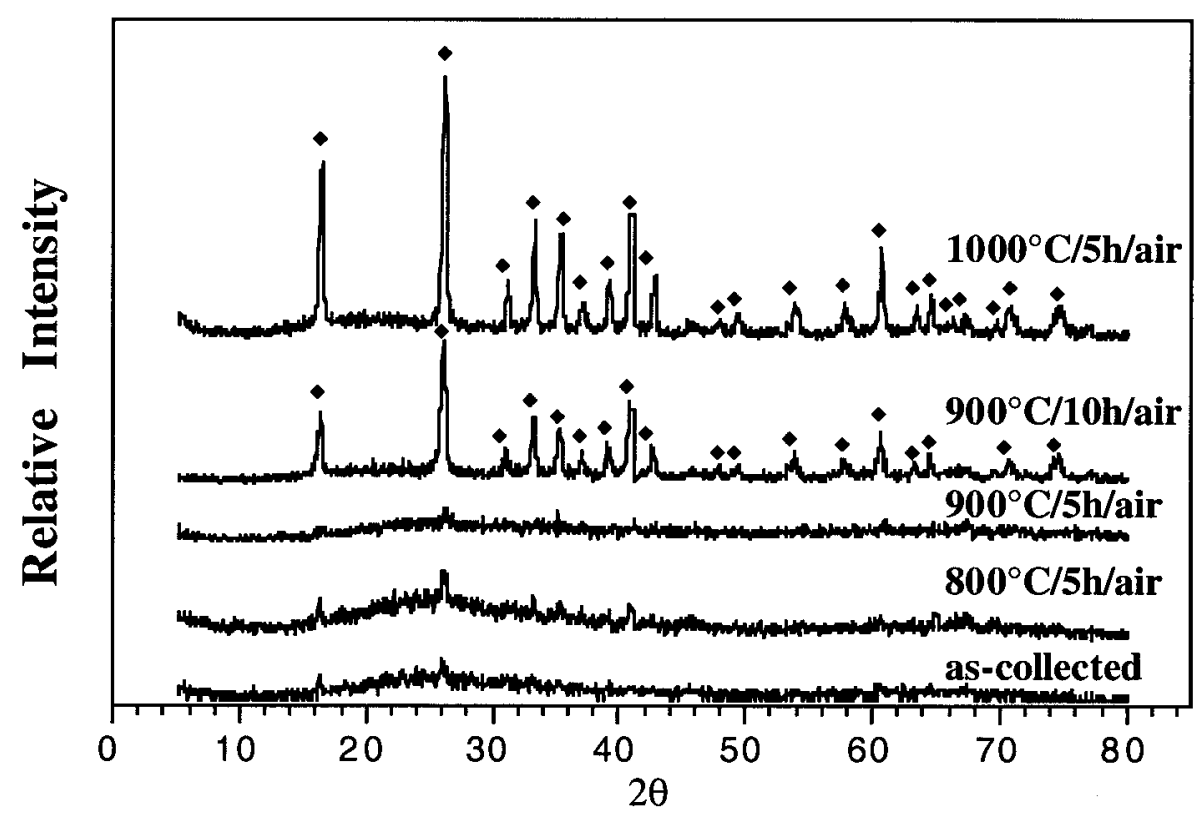

Fig. 6. Powder XRD patterns of as-processed mullite nanopowders heated (using a "temperature/time/air" notation) to selected temperatures for selected times. Note the slight crystallinity of the as-processed powder. (" " represents a mullite peak, according to ICDD Powder Diffraction File Card No. 15-776.) 


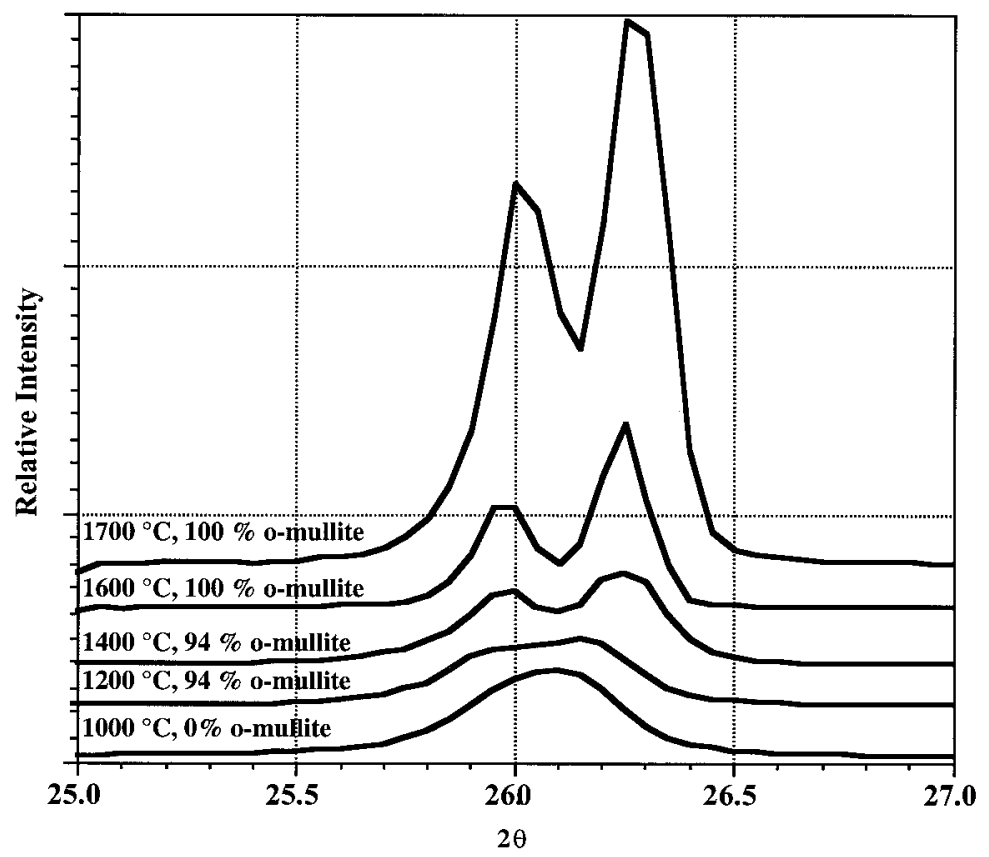

Fig. 7. Peak splitting of $26.15^{\circ} 2 \theta$ into $25.97^{\circ}$ and $26.26^{\circ} 2 \theta$ (the (120) and (210) peaks, respectively) during phase transformation from tetragonal mullite to orthorhombic mullite. At $1200^{\circ}-1400^{\circ} \mathrm{C}$, the samples are $94 \%$ orthorhombic; at $1600^{\circ} \mathrm{C}$, the sample is $100 \%$ orthorhombic.

peaks (at $25.97^{\circ}$ and $26.26^{\circ} 2 \theta$, respectively) for ICDD Powder Diffraction File Card No. 15-776 was used as a reference (mullite crystallized at $1600^{\circ} \mathrm{C}$ ).

These calculations indicate that the $1000^{\circ} \mathrm{C}$ sample is $100 \%$ tetragonal. No peak splitting seems to have occurred, although the very small crystallite size (very broad peak(s)) may hide the presence of some orthorhombic phase. At $1200^{\circ} \mathrm{C}$, the sample seems to be $>90 \%$ orthorhombic. Assessment of the $1400^{\circ} \mathrm{C}$ sample suggests that it also is $>90 \%$ orthorhombic, with the $1600^{\circ} \mathrm{C}$ samples being $100 \%$ orthorhombic phase. We note that, because of the crystallite sizes, the differences between the $1400^{\circ} \mathrm{C}$ sample and the $1600^{\circ} \mathrm{C}$ sample may be too small to distinguish between $100 \%$ and $>90 \%$ orthorhombic phase. Thus, at $1400^{\circ} \mathrm{C}$, conversion may be complete. Additional work is necessary to establish this possibility.

The absence of a spinel phase (such as that detected in single-phase precursors produced via sol-gel routes) ${ }^{32}$ indicates a high degree of homogeneity, which likely is due to better atomic mixing that is provided by the polymer precursor. Despite this observation, complete conversion to $o$-mullite does not occur until $1400^{\circ} \mathrm{C}$, when the (120) and (210) peaks split from $26.15^{\circ} 2 \theta$ in the tetragonal phase to $25.97^{\circ}$ and $26.26^{\circ} 2 \theta$, respectively, in the orthorhombic phase, per $\mathrm{Li}$ and Thomson. ${ }^{29(\mathrm{~b})}$

The crystallite sizes, according to XRD $\left(D_{\mathrm{XRD}}\right)$, were calculated using the diffraction peak of the (120) plane $\left(2 \theta=26.15^{\circ}\right.$ for samples heated at $\leq 1200^{\circ} \mathrm{C}, 2 \theta=26.26^{\circ}$ for samples heated to $>1200^{\circ} \mathrm{C}$ ) from ICDD Powder Diffraction File Card No. 15-776 and the Debye-Scherrer equation. ${ }^{33}$ The $D_{\text {XRD }}$ values of the heated samples are listed in Table II.

The mean crystallite size $\left(D_{\mathrm{XRD}}\right.$, after $1000^{\circ} \mathrm{C}$ for $\left.5 \mathrm{~h}\right)$ for nanosized $t$-mullite, as calculated from XRD line-broadening methods, was $36 \pm 2 \mathrm{~nm}$. The $D_{\mathrm{BET}}$ value, after heating at $1000^{\circ} \mathrm{C}$ for $5 \mathrm{~h}$, as calculated from the SSA, was $51 \pm 3 \mathrm{~nm}$. Note that the TEM studies (Fig. 5) show that the particles have rough surfaces, which could explain the disparity in the two techniques. These results are better than the mean particle size that was determined from particle-size-distribution analyses, which actually gave size distributions for the necked particles.

\section{(7) Diffuse Reflectance Infrared Fourier Transform Spectroscopy}

The DRIFTS analysis of the as-prepared, calcined, and crystallized nano-mullite (Fig. 8) show a tetragonal-to-orthorhombic
Table II. $d$-spacings of Various Planes of Mullite $\left(3 \mathrm{Al}_{2} \mathrm{O}_{3} \cdot 2 \mathrm{SiO}_{2}\right), \theta-\mathrm{Al}_{2} \mathrm{O}_{3}$, and $\beta-\mathrm{Al}_{2} \mathrm{O}_{3}^{\dagger}$

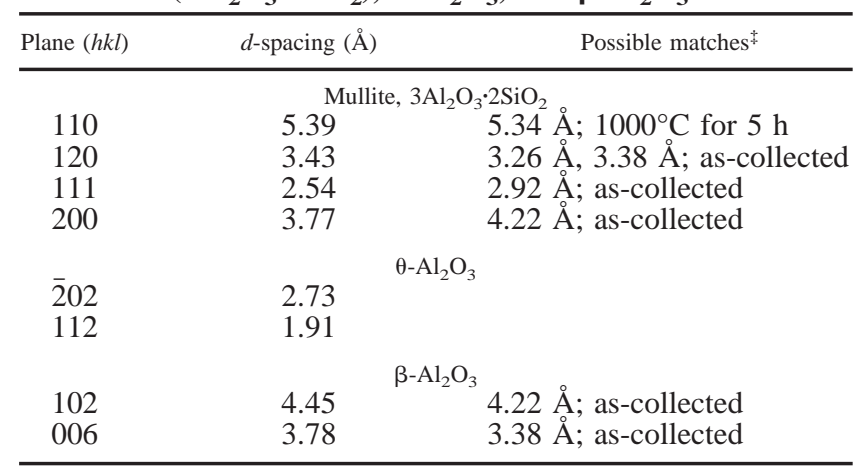

Data taken from ICDD Powder Diffraction File Card Nos. 15-776 (for mullite), 35-121 (for $\theta-\mathrm{Al}_{2} \mathrm{O}_{3}$ ), and 10-414 (for $\beta-\mathrm{Al}_{2} \mathrm{O}_{3}$ ). ${ }^{*}$ Measured interplanar distances of $35-121$ (for $\theta-\mathrm{Al}_{2} \mathrm{O}_{3}$ ), and 10-414 (for $\beta-\mathrm{Al}_{2} \mathrm{O}_{3}$ ). ${ }^{*}$ Measured interplanar distances of
as-processed mullite and nano-mullite heated to $1000^{\circ} \mathrm{C}$ for $5 \mathrm{~h}$ are matched with as-processed multite
these $d$-spacings.

mullite transformation that occurs at the same temperatures as those observed in the XRD studies. A standard mullite IR spectrum consists of tetrahedral $\mathrm{AlO}_{4} v(\mathrm{Al}-\mathrm{O})$ vibrations at 740 and 830 $\mathrm{cm}^{-1}$, octahedral $\mathrm{AlO}_{6} v(\mathrm{Al}-\mathrm{O})$ vibrations at $530-680 \mathrm{~cm}^{-1}$, and tetrahedral $\mathrm{SiO}_{4} v(\mathrm{Si}-\mathrm{O})$ vibrations at 1130 and 1170 $\mathrm{cm}^{-1} .34-36$

\section{(8) Bond Vibrations}

(A) $\mathrm{AlO}_{4} v(\mathrm{Al}-\mathrm{O})$ : Vibrations due to $\mathrm{AlO}_{4}$ tetrahedra appear at $830 \mathrm{~cm}^{-1}$ (literature value) in the as-processed nanomullite-composition powder and remain present in samples that have been heated to higher temperatures. A well-defined band at $740 \mathrm{~cm}^{-1}$, typical of $\mathrm{AlO}_{4} v(\mathrm{Al}-\mathrm{O})$ vibrations, develops when the powder is heated to $900^{\circ} \mathrm{C}$ for $10 \mathrm{~h}$, coincident with the conversion to $t$-mullite. This band appears with the crystallization of $t$-mullite, as also corroborated by the above-discussed XRD data.

Both bands intensify as crystallization continues during heating at $1000^{\circ} \mathrm{C}$ for $5 \mathrm{~h}$ and then become fully resolved when the conversion to $o$-mullite occurs at temperatures of $>1200^{\circ} \mathrm{C}$. The above-described results differ slightly from those of Kansal et al. ${ }^{14}$ who observed a broad envelope that was centered at 


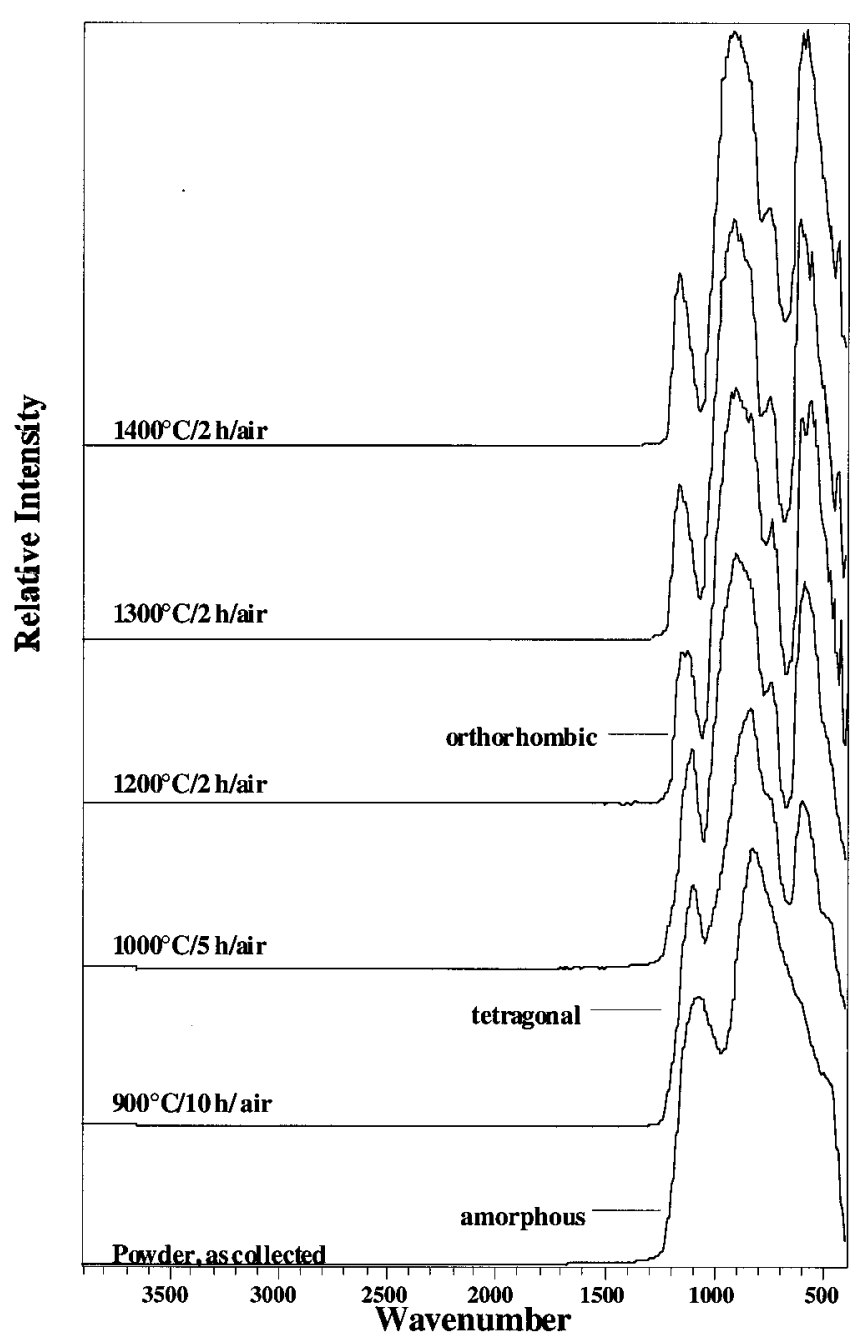

Fig. 8. DRIFT spectra of as-processed mullite-composition nanopowders heated to selected temperatures for selected times ("temperature/time/air" notation has been used).
$700 \mathrm{~cm}^{-1}$, because of a combination of $\mathrm{AlO}_{4}$ and $\mathrm{AlO}_{6} v(\mathrm{Al}-\mathrm{O})$ vibrations, which shifts to $720 \mathrm{~cm}^{-1}$ at $900^{\circ} \mathrm{C}$, then to $740 \mathrm{~cm}^{-1}$ (literature value) at $1000^{\circ} \mathrm{C}$, where it intensifies on heating to $1300^{\circ} \mathrm{C}$. The absence of the broad envelope at $700 \mathrm{~cm}^{-1}$ in the nano-mullite powders may again be attributed to the fact that they have already been exposed to a temperature of $2000^{\circ} \mathrm{C}$.

(B) $\mathrm{AlO}_{\sigma} v(\mathrm{Al}-\mathrm{O}):$ In the as-prepared powder, bands at $530-680 \mathrm{~cm}^{-1}$ that are attributable to octahedral $v(\mathrm{Al}-\mathrm{O})$ vibrations are absent. When the powder is heated at $900^{\circ} \mathrm{C}$ for $5 \mathrm{~h}$, a $v(\mathrm{Al}-\mathrm{O})$ band appears at $600 \mathrm{~cm}^{-1}$, indicating formation of octahedral $\mathrm{AlO}_{6}$ chains in $t$-mullite. This band continues to sharpen and intensify on further heating.

(C) $\mathrm{SiO}_{4} v(\mathrm{Si}-\mathrm{O})$ : The band located at $\sim 1100 \mathrm{~cm}^{-1}$ in samples that have been heated at $900^{\circ} \mathrm{C}$ for $10 \mathrm{~h}$ is attributed to tetrahedral $\mathrm{SiO}_{4} v(\mathrm{Si}-\mathrm{O})$ vibrations, such as those observed for $\mathrm{SiO}_{2}$, as also reported by Kansal et al. ${ }^{14}$ When the powder is heated at $1000^{\circ} \mathrm{C}$ for $5 \mathrm{~h}$, the $1100 \mathrm{~cm}^{-1}$ band sharpens as the formation of $\mathrm{Al}_{2} \mathrm{O}_{3}$-rich $t$-mullite forces $\mathrm{SiO}_{2}$ to segregate out. At higher temperatures, the $1100 \mathrm{~cm}^{-1}$ band splits into two bands, at 1170 and $1120 \mathrm{~cm}^{-1}$, which is typically observed for $o$-mullite formation as the segregated $\mathrm{SiO}_{2}$ is readsorbed. ${ }^{34-36}$

\section{(9) Transmission Electron Microscopy}

TEM was used to elucidate crystallite size and shape, indexmatch the phases, and identify phase segregation. A TEM micrograph of as-processed mullite particles that exhibit a small degree of crystallinity is shown in Fig. 9. The selected-area diffraction (SAD) patterns and interplanar distances of 3.26 and $2.92 \AA$ are consistent with the $(120) /(111)$ planes of mullite (see Table II). Note that differences of $<15 \%$ in the $d$-spacings are acceptable when index-matching the measured interplanar distances using high-resolution transmission electron microscopy (HRTEM) ${ }^{37}$

For the as-processed mullite powder, the SAD pattern (see Fig. 10 ) and measured interplanar distances of 4.22 and $3.38 \AA$, as well as the interplanar angle of $67^{\circ}$, are consistent with the $(200) /(120)$ planes of mullite. These interplanar distances also are consistent with the (102)/(006) planes of $\beta-\mathrm{Al}_{2} \mathrm{O}_{3}$ (ICDD Powder Diffraction File Card No. 10-414). $\theta-\mathrm{Al}_{2} \mathrm{O}_{3}$ was thought to possibly segregate in the formation of mullite particles; however, an index match with $\theta-\mathrm{Al}_{2} \mathrm{O}_{3}$ (ICDD Powder Diffraction File Card No. 35-121) does not support the presence of the $(\overline{202}) /(112)$ planes of $\theta-\mathrm{Al}_{2} \mathrm{O}_{3}$.

The TEM micrograph in Fig. 11 shows samples that were heated at $1000^{\circ} \mathrm{C}$ for $5 \mathrm{~h}$. All the particles have exactly the same orientation, which suggests epitaxial crystallization. The SAD

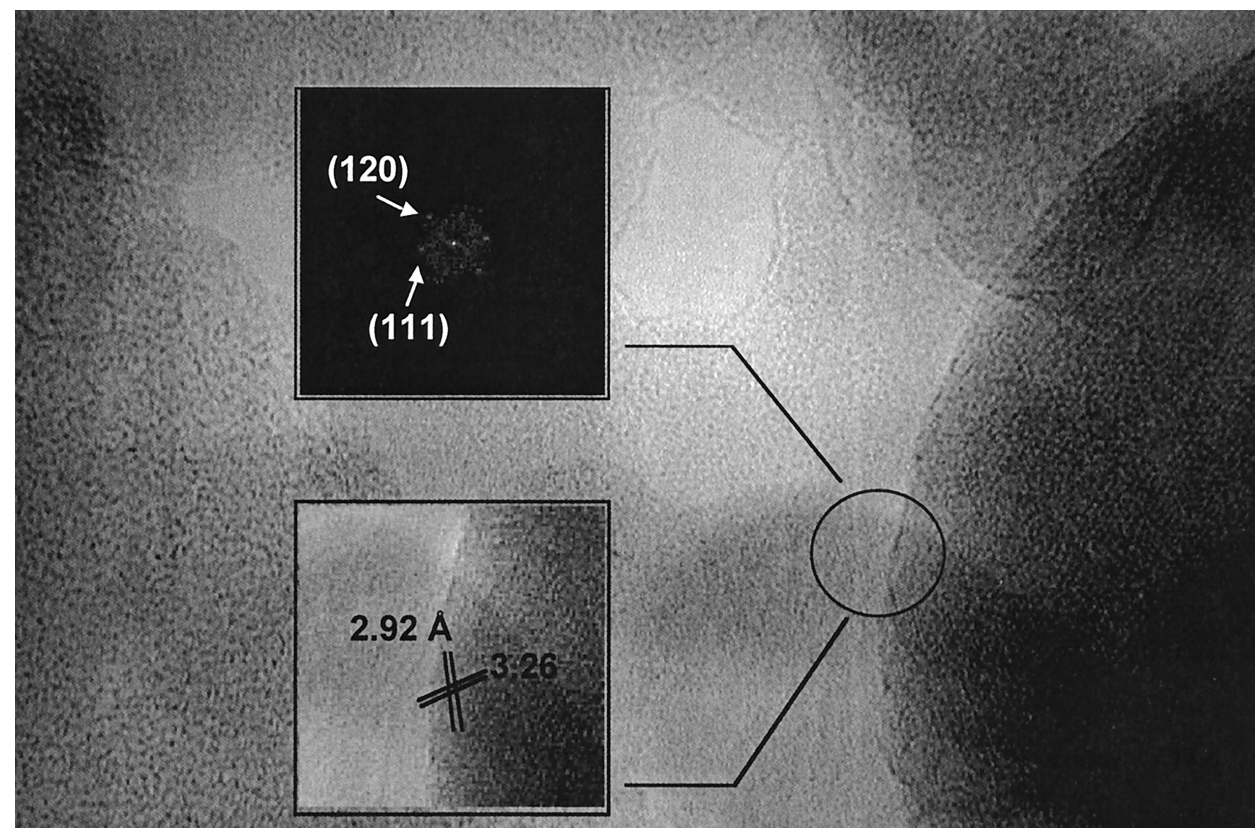

Fig. 9. HRTEM micrograph of as-processed mullite-composition nanopowder, showing crystalline traces in the particles. Diffractogram in inset is consistent with the (120)/(111) planes of mullite. 


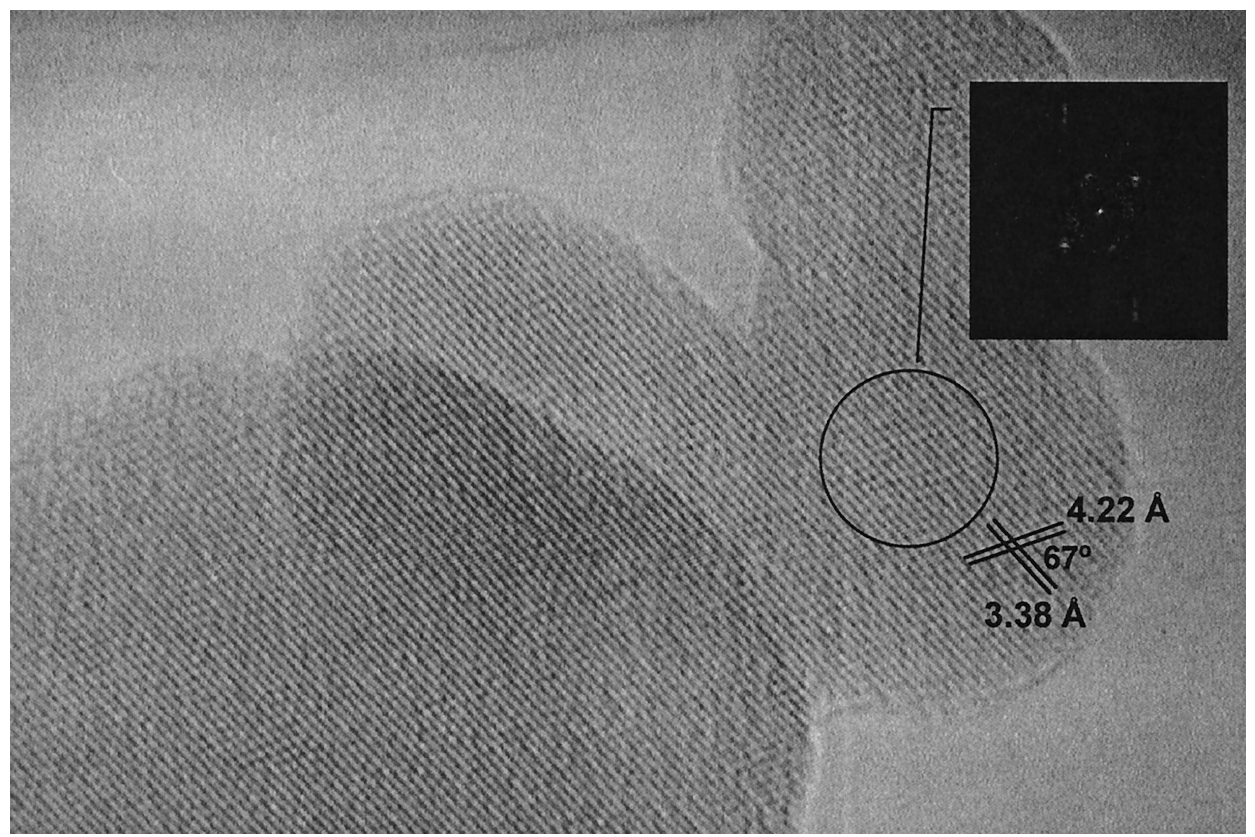

Fig. 10. HRTEM micrograph of as-processed mullite nanopowders (an SAD pattern is shown in the inset). All the particles have exactly the same orientation, suggesting that nucleation from one site leads to epitaxial crystallization.

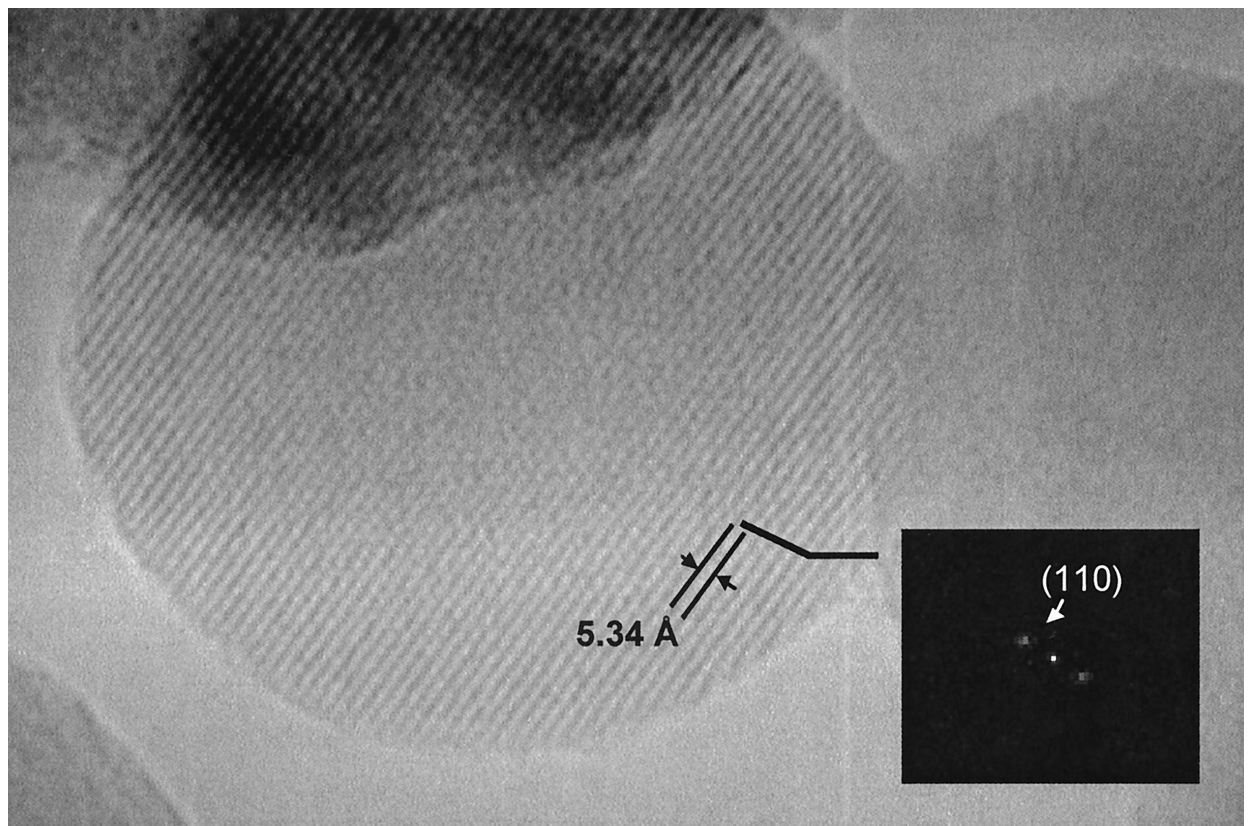

Fig. 11. HRTEM micrograph of nano-mullite formed after $1000^{\circ} \mathrm{C}$ for $5 \mathrm{~h}$, showing the (110) planes (an SAD pattern is shown in the inset).

pattern corresponds to the (110) planes of mullite. The measured interplanar distance of $5.34 \AA$ observed in Fig. 11 also corresponds to the (110) planes of mullite.

Following the above-described characterization, we conducted preliminary densification studies, using simple powdercompaction methods.

\section{(10) Densification}

Compacts were pressed using (i) powders pretreated at $800^{\circ} \mathrm{C}$ for $5 \mathrm{~h}$, to remove trace amounts of surface contaminants ( e.g., carbon), without initiating crystallization, and (ii) powders pretreated at $1000^{\circ} \mathrm{C}$ for $5 \mathrm{~h}$, to crystallize $t$-mullite. Compaction was performed without binder or sintering aids, to minimize the effects of additives. The object of these studies was to establish baseline conditions that would allow more-detailed studies to be conducted at a later date. Our preliminary goal was to identify processing windows that offered the most potential for full densification with minimal grain growth.

Powders were compacted $(12.7 \mathrm{~mm} \times 2 \mathrm{~mm})$ at loads of 90 or $180 \mathrm{MPa}$. All the compacts were sintered to $1600^{\circ} \mathrm{C}$, at varying ramp rates, and held at that temperature for $2 \mathrm{~h}\left(10^{\circ} \mathrm{C} / \mathrm{min}\right.$ to $1600^{\circ} \mathrm{C}$ for $2 \mathrm{~h}$ ). Lower temperatures did not permit full densification, because of the low self-diffusion rates of mullite. Density measurements first were calculated using mass/volume measurements, and then via the Archimedes method. Powders compacted at $180 \mathrm{MPa}$ attained densities that were similar to powders compacted at $90 \mathrm{MPa}$. Thus, all further studies were conducted using compacts that had been pressed at $90 \mathrm{MPa}$.

In sintering studies on yttrium aluminum garnet (YAG) fibers, we established that grain growth competed quite strongly with densification in a system that was known to have low diffusion 


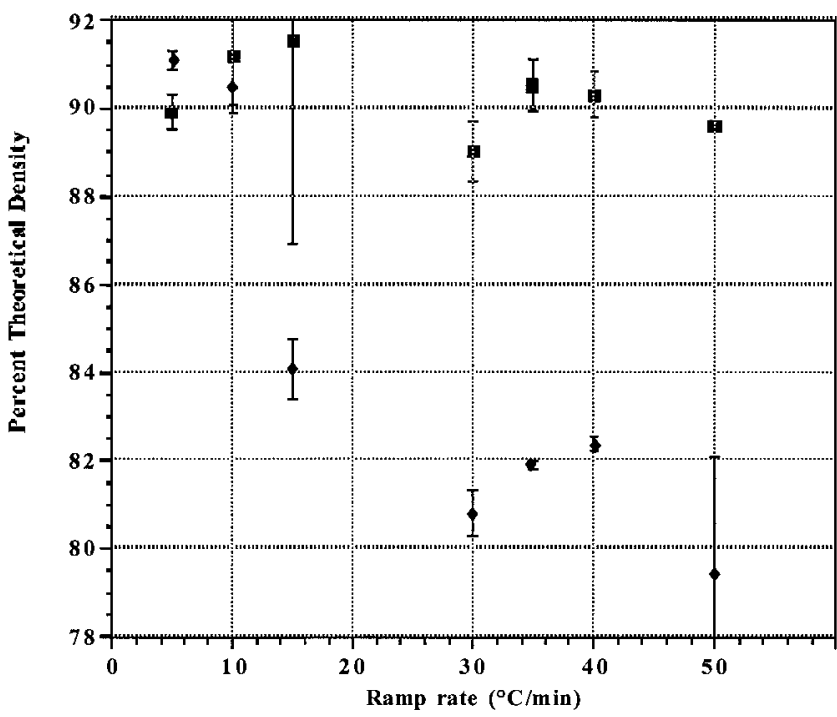

Fig. 12. Density of mullite compacts prepared from powder calcined at $(\triangleleft) 800^{\circ} \mathrm{C}$ for $5 \mathrm{~h}$ or $(\square) 1000^{\circ} \mathrm{C}$ for $5 \mathrm{~h}$ (each compacted at $90 \mathrm{MPa}$ ), sintered at various ramp rates to $1600^{\circ} \mathrm{C}$ for $2 \mathrm{~h}$.

rates. ${ }^{38}$ We found that increases in ramp rates allowed densification to compete with grain growth, which allowed full densification with modest control of the grain size. On this basis, and given the low diffusion rates for crystalline mullite, we explored the effects of ramp rates on densification.

The densities of compacts that have been sintered at various ramp rates are shown in Fig. 12. For the samples that have been calcined at $800^{\circ} \mathrm{C}$ for $5 \mathrm{~h}$, the densities do not change significantly when the ramp rates increase from $5^{\circ} \mathrm{C} / \mathrm{min}$ (relative density of $91 \%$ ) to $10^{\circ} \mathrm{C} / \mathrm{min}$ (relative density of $90 \%$ ). Then, the densities decrease as the ramp rates are increased further to $50^{\circ} \mathrm{C}$ (relative density of $77 \%$ ). For the samples that have been calcined at $1000^{\circ} \mathrm{C}$ for $5 \mathrm{~h}$, the relative densities remain in the range of $89 \%-93 \%$ for ramp rates in the range of $5^{\circ}-50^{\circ} \mathrm{C} / \mathrm{min}$, although the highest densities were obtained with ramp rates of $10^{\circ}-15^{\circ} \mathrm{C} / \mathrm{min}$.

Several explanations for this behavior are possible; however, without the extensive studies that are planned in the future, a detailed discussion of all the possibilities is not realistic. Two salient points must be considered. First, the material that was heat-treated at $800^{\circ} \mathrm{C}$ is mostly amorphous but transforms to $t$-mullite and then $o$-mullite as the compacts are ramped to $1600^{\circ} \mathrm{C}$. In addition, heating the nanopowders at $900^{\circ} \mathrm{C}$ for $5 \mathrm{~h}$ does not promote crystallization, whereas heating for $10 \mathrm{~h}$ (Fig. 6) does. This observation suggests that nucleation is slow; however, once it does occur, crystallization is rapid.

Given these observations, it is possible to suggest that, at sufficiently high ramp rates, partial sintering occurs before crystallization. Thus, some surface area is lost in the formation of necks, etc. However, at some point, nucleation occurs, which results in rapid crystallization and a decrease in diffusivity. The loss of surface area, coupled with the lower diffusion rates, would be expected to lead to lower final densities. Support for this scenario comes from the TEM image in Fig. 11, where epitaxial crystallization is observed, which suggests that one nucleus has formed and crystallization has occurred through the particle necks.

Still, other possible explanations exist. If we compare the TEM images in Figs. 4 and 5, the particle surfaces of the material that was heated at $1000^{\circ} \mathrm{C}$ for $5 \mathrm{~h}$ are visibly roughened, possibly as a result of the crystallization process. Roughening may lead to increased surface area not detected via BET analysis, which might aid in densification. However, more work must be done to understand the events that actually occur.

In contrast to the $800^{\circ} \mathrm{C}$ materials, the compacts that have been heated at $1000^{\circ} \mathrm{C}$ for $5 \mathrm{~h}$ are already crystalline. Thus, competing transformation processes will not inhibit densification and, within the error limits of the measurements, the densities that are observed at all heating rates are very similar ( $\sim 90 \%$ of theoretical). We believe that these values are quite good for powder compacts that have been pressureless-sintered and produced without compaction aids. In future studies, we hope to improve on these results through the use of precursor binders. The possibility that microstructural evolution can be controlled remains to be determined.

\section{(11) Scanning Electron Microscopy}

SEM was used to examine the effects of sintering on microstructural evolution. Micrographs of fresh fracture surfaces of compacts $(90 \mathrm{MPa})$ are shown in Fig. 13. These micrographs suggest that failure occurs via intergranular, rather than crossgranular, fracture. Again, more-detailed studies, using more samples, are required to fully delineate the fracture process.
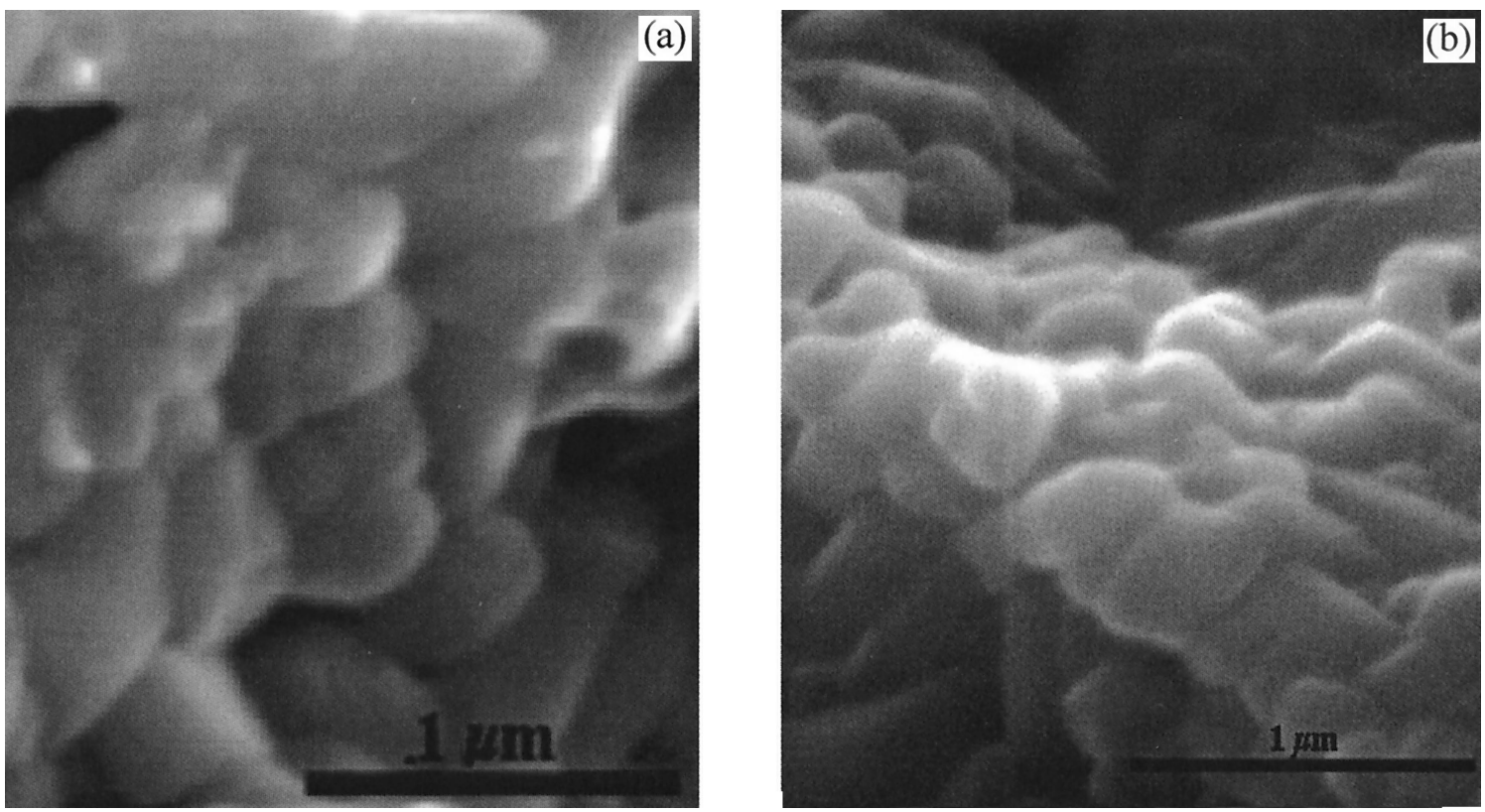

Fig. 13. SEM micrograph of compacted, sintered nano-mullite powders (powder treated at (a) $800^{\circ} \mathrm{C}$ for $5 \mathrm{~h}$ in air $\left(92 \%\right.$ dense), and (b) $1000^{\circ} \mathrm{C}$ for $5 \mathrm{~h}$ in air $\left(91 \%\right.$ dense)). Each powder was compacted at $90 \mathrm{MPa}$, and then each compact was heated to $1600^{\circ} \mathrm{C}$ for $2 \mathrm{~h}$ in air. 
Following heat treatments at $1600^{\circ} \mathrm{C}$ and conversion to $o$-mullite, the grain sizes are $300-420 \mathrm{~nm}$ (via line-fraction analysis). These values are quite reasonable for initial efforts; however, we believe that, with better control of the FSP process, even-smaller average particle sizes can be obtained, which, in turn, will provide better control of both densification and microstructural evolution.

\section{Conclusions}

Ultrafine mullite $\left(3 \mathrm{Al}_{2} \mathrm{O}_{3} \cdot 2 \mathrm{SiO}_{2}\right)$ particles were produced successfully via the flame spray pyrolysis of a polymer precursor. Powder production rates were $100-300 \mathrm{~g} / \mathrm{h}$. The formation of ultrafine particles occurs via combustion of the reactants to form metal-oxide vapors, which then form clusters that, in turn, form particles that grow to $>10 \mathrm{~nm}$ in size. The resulting powders (40-80 nm) were amorphous (according to X-ray diffractometry (XRD)) and converted to tetragonal mullite (after heating at $900^{\circ} \mathrm{C}$ for $10 \mathrm{~h}$ ) and then orthorhombic mullite (after heating to $\left.>1300^{\circ} \mathrm{C}\right)$. The BET particle surface area $\left(43 \mathrm{~m}^{2} / \mathrm{g}\right)$ decreased (to $0.4 \mathrm{~m}^{2} / \mathrm{g}$ ) when the samples were heated to $1600^{\circ} \mathrm{C}$. Diffuse reflectance infrared Fourier transform spectroscopy corroborated the phase transformations that were observed in the XRD studies.

Nano-mullite particles were calcined at $800^{\circ}$ or $1000^{\circ} \mathrm{C}$ for $5 \mathrm{~h}$, then compacted at 90 or $180 \mathrm{MPa}$ and sintered at $1600^{\circ} \mathrm{C}$ using various ramp rates. Compacts with a final density of $91 \% \pm 2 \%$ of the theoretical density and grain sizes of $<420 \mathrm{~nm}$ were obtained.

\section{Acknowledgments}

The authors thank Dr. Martha Fletcher of the Army Research Laboratories for the initial financial and enthusiastic support that started all their nanopowder efforts. (Dr. Fletcher is now at Natick Laboratories.) The authors also thank the reviewers for their help to make this paper a better contribution. The authors also would like to thank Prof. X. Pan for help in interpreting the HRTEM data.

\section{References}

${ }^{1}$ M. G. M. U. Ismail, H. Tsunatori, and Z. Nakai, "Preparation of Mullite Cordierite Composite Powders by the Sol-Gel Method: Its Characteristics and Sintering," J. Am. Ceram. Soc., 73 [3] 537-43 (1990).

${ }^{2}$ H. Schneider, K. Okada, and J. A. Pask, Mullite and Mullite Ceramics. Wiley, Chichester, U.K., 1994.

${ }^{3}$ P. C. Dokko, J. A. Pask, and K. S. Mazdiyasni, "High-Temperature Mechanical Properties of Mullite Under Compression," J. Am. Ceram. Soc., 60 [3-4] 150-55 (1977)

${ }^{4}$ S. Sōmiya and Y. Hirata, "Mullite Powder Technology and Application in Japan," Am. Ceram. Soc. Bull., 70 [10] 1624-32 (1991).

${ }^{5}$ Y. Hirata, M. Matsuda, K. Takeshima, R. Yamashita, M. Shibuya, M. Schmucker, and H. Schneider, "Processing and Mechanical Properties of Laminated Composites of Mullite/Woven Fabrics of Si-Ti-C-O Fibers," J. Eur. Ceram. Soc., 16, 315-20 (1996).

${ }^{6}$ I. A. Aksay, D. M. Dabbs, and M. Sarikaya, "Mullite for Structural, Electronic, and Optical Applications," J. Am. Ceram. Soc., 74 [10] 2343-58 (1991).

${ }^{7}$ M. D. Sacks, H.-W. Lee, and J. A. Pask, "A Review of Powder Preparation Methods and Densification Procedures for Fabricating High-Density Mullite"; pp. 167-207 in Ceramic Transactions, Vol. 6, Mullite and Mullite Matrix Composites Edited by S. Sōmiya, R. F. Davis, and J. A. Pask. American Ceramic Society, Westerville, $\mathrm{OH}, 1990$

${ }^{8}$ B. Sonuparlak, "Sol-Gel Processing of IR Transparent Mullite," Adv. Ceram. Mater., 3 [3] 263-67 (1988).

${ }^{9}$ R. R. Tummala, "Ceramic and Glass Ceramic Packaging in the 1990s," J. Am. Ceram. Soc., 74 [5] 895-908 (1991)

${ }^{10}$ Dj. Janackovic, V. Jokanovic, Lj. Kostic-Gvozdenovic, Lj. Zivkovic, and D. Uskokovic, "Synthesis, Morphology, and Formation Mechanism of Mullite Particles Produced by Ultrasonic Spray Pyrolysis," J. Mater. Res., 11 [7] $1706-16$ (1996).

${ }^{11}$ W.-C. Wei and J. W. Halloran, "Transformation Kinetics of Diphasic Aluminosilicate Gels," J. Am. Ceram. Soc., 71 [7] 581-87 (1988).

${ }^{12}$ N. Shinohara, D. M. Dabbs, and I. A. Aksay, "Infrared Transparent Mullite through Densification of Monolithic Gels at $1250^{\circ} \mathrm{C}$," Proc. SPIE-Int. Soc. Opt. Eng., 683, 19-24 (1986)
${ }^{13}$ W.-C. Wei and J. W. Halloran, "Phase Transformation of Diphasic Aluminosilicate Gels," J. Am. Ceram. Soc., 71 [3] 166-72 (1988).

${ }^{14}$ P. Kansal, R. M. Laine, and F. Babonneau, "A Processable Mullite Precursor Prepared by Reacting Silica and Aluminum Hydroxide with Triethanolamine in Ethylene Glycol: Structural Evolution on Pyrolysis," J. Am. Ceram. Soc., 80 [10] 2597-606 (1997).

${ }^{15}$ (a)C. R. Bickmore, K. F. Waldner, D. R. Treadwell, and R. M. Laine, "Ultrafine Spinel Powders by Flame Spray Pyrolysis of a Magnesium Aluminum Double Alkoxide," J. Am. Ceram. Soc., 79 [5] 1419-23 (1996). (b)C. R. Bickmore, K. F. Waldner, R. Baranwal, T. Hinklin, D. R. Treadwell, and R. M. Laine, "Ultrafine Titania by Flame Spray Pyrolysis of a Titanatrane Complex," J. Eur. Ceram. Soc., 18 287-97 (1998). (c)R. M. Laine, K. Waldner, C. Bickmore, and D. R. Treadwell, "Ultrafine Powders by Flame Spray Pyrolysis," U.S. Pat. No. 5958 361, Sept. 28, 1999.

${ }^{16}$ A. C. Sutorik, S. S. Neo, D. R. Treadwell, and R. M. Laine, "Synthesis of Ultrafine $\beta^{\prime \prime}$-Alumina Powders via Flame Spray Pyrolysis of Polymeric Precursors," J. Am. Ceram. Soc., 81 [6] 1477-86 (1998).

${ }^{17}$ R. M. Laine, D. R. Treadwell, B. L. Mueller, C. R. Bickmore, K. F. Waldner, and T. R. Hinklin, "Processable Aluminosilicate Alkoxide Precursors from Metal Oxides and Hydroxides: The Oxide One Pot Synthesis (OOPS) Process," J. Chem. Mater., 6, 1441-43 (1996).

${ }^{18}$ S.-L. Chung, Y.-C. Sheu, and M.-S. Tsai, "Formation of $\mathrm{SiO}_{2}, \mathrm{Al}_{2} \mathrm{O}_{3}$, and $3 \mathrm{Al}_{2} \mathrm{O}_{3} \cdot 2 \mathrm{SiO}_{2}$ Particles in a Counterflow Diffusion Flame," J. Am. Ceram. Soc., 75 [1] 117-23 (1992)

${ }^{19}$ K. Okuyama, Y. Kousaka, N. Tohge, S. Yamamoto, J. J. Wu, R. C. Flagan, and J. H. Seinfeld, "Production of Ultrafine Metal Oxide Aerosol Particles by Thermal Decomposition of Metal Alkoxide Vapors," J. AIChE, 32 [12] 2010-19 (1986).

${ }^{20} \mathrm{Y}$. Suyama and A. Kato, " $\mathrm{TiO}_{2}$ Produced by Vapor-Phase Oxygenolysis of $\mathrm{TiCl}_{4}$, , J. Am. Ceram. Soc., 59 [3-4] 146-49 (1976)

${ }^{21}$ C. Roger, T. Corbitt, C. Xu, D. Zeng, Q. Powell, C. D. Chandler, M. Nyman, M. J. Hampden-Smith, and T. T. Kodas, "Principles of Molecular Precursor Selection for Aerosol Synthesis of Materials," Nanostruct. Mater., 4 [5] 529-35 (1994).

${ }^{22}$ A. Gurav, T. Kodas, T. Pluym, and Y. Xiong, "Aerosol Processing of Materials," Aerosol Sci. Technol., 19, 411-52 (1993).

${ }^{23}$ G. D. Ulrich and N. S. Subramanian, "Particle Growth in Flames, III. Coalescence as a Rate-Controlling Process," Combust. Sci. Technol., 17, 119-26 (1977).

${ }^{24}$ D. R. Lide (ed.), Handbook of Chemistry and Physics; pp. 4-37-98 and 6-109-10. CRC Press, New York, 1995

${ }^{25}$ K. A. Moore, J. Cesarano III, D. M. Smith, and T. T. Kodas, "Synthesis of Submicrometer Mullite Powder via High-Temperature Aerosol Decomposition," J. Am. Ceram. Soc., 75 [1] 213-15 (1992).

${ }^{26}$ H. Suzuki, Y. Tomokiyo, Y. Suyama, and H. Saito, "Preparation of Ultrafine Mullite Powders from Metal Alkoxides," J. Ceram. Soc. Jpn. Int. Ed., 96, 67-73 (1988).

${ }^{27}$ M. Ge, H. Yang, Z. Jiang, Y. Wang, and F. Zhang, "Ultrafine Pure Mullite Powder Prepared by Sol-Gel Method," J. Non-Cryst. Solids, 147-148, 565-68 (1992).

${ }^{28}$ (a)I. A. Aksay and J. A. Pask, "The Silica-Alumina System: Stable and Metastable Equilibria at 1.0 Atmosphere," Science, 183 [4120] 69-71 (1974). (b)I. A. Aksay and J. A. Pask, "Stable and Metastable Equilibria in the System $\mathrm{SiO}_{2}-\mathrm{Al}_{2} \mathrm{O}_{3}$," J. Am. Ceram. Soc., 58 [11-12] 507-12 (1975).

${ }^{29}$ (a)Y. Wang and W. J. Thomson, "Mullite Formation from Nonstoichiometric Slow Hydrolyzed Single Phase Gels," J. Mater. Res., 10 [4] 912-17 (1995). (b)D. X. $\mathrm{Li}$ and W. J. Thompson, "Tetragonal to Orthorhombic Transformation During Mullite Formation," J. Mater. Res., 6 [4] 819-24 (1991).

${ }^{30}$ E. A. Barringer, R. Brook, and H. K. Bowen, "The Sintering of Monodisperse $\mathrm{TiO}_{2}$ "; pp. 1-21 in Sintering and Heterogeneous Catalysis. Edited by G. C. Kuczynski, A. E. Miller, and G. A. Sargent. Plenum Press, New York, 1984.

${ }^{31}(\mathrm{a}) \mathrm{H}$. Schneider and T. Rymon-Lipinski, "Occurrence of Pseudotetragonal Mullite," J. Am. Ceram. Soc., 71 [3] C-162-C-164 (1988). (b)H. Schneider, R. X. Fisher, and D. Voll, "Mullite with Lattice Constants $a>b$," J. Am. Ceram. Soc. 76 [7] 1879-81 (1983).

${ }^{32}$ A. Chakravorty, "Intermediate Si-Al Spinel Phase Formation in Phase Transformation of Diphasic Mullite Gel," J. Mater. Sci., 28, 3839-44 (1993).

${ }^{33} \mathrm{P}$. Scherrer, "Bestimmung der Grosse und der Inneren Struktur von Kolloidteilchen mittels Rontgenstrahlen," Gott. Nachr., 2, 98-100 (1918).

${ }^{34} \mathrm{P}$. Tarte, "Infrared Study of Orthosilicates and Orthogermanates: II," Spectrochim. Acta, 19 [1] 25-47 (1963).

${ }^{35} \mathrm{P}$. Tarte, "Infrared Spectra of Inorganic Aluminates and Characteristic Vibrational Frequencies of $\mathrm{AlO}_{4}$ Tetrahedra and $\mathrm{AlO}_{6}$ Octahedra," Spectrochim. Acta, Part A, 23 [7] 2127-43 (1967).

${ }^{36}$ H. J. Percival, J. F. Duncan, and P. K. Foster, "Interpretation of the KaoliniteMullite Reaction Sequence from Infrared Absorption Spectra," J. Am. Ceram. Soc., 57 [2] 57-61 (1974).

${ }^{37}$ J. Jiang, Dept. of Materials Science and Engineering, University of Michigan, Ann Arbor, MI; private communication.

${ }^{38}$ Y. Liu, Z.-F. Zhang, J. Halloran, and R. M. Laine, "Yttrium Aluminum Garnet Fibers from Metalloorganic Precursors," J. Am. Ceram. Soc., 81 [3] 629-45 (1998). 